\title{
Optimising functional outcomes in rectal cancer surgery
}

\author{
Fabio Nocera ${ }^{1} \cdot$ Fiorenzo Angehrn ${ }^{1} \cdot$ Markus von Flüe ${ }^{1} \cdot$ Daniel C. Steinemann ${ }^{1,2}$ (])
}

Received: 9 July 2020 / Accepted: 13 July 2020 / Published online: 26 July 2020

(C) The Author(s) 2020

\begin{abstract}
Background By improved surgical technique such as total mesorectal excision (TME), multimodal treatment and advances in imaging survival and an increased rate of sphincter preservation have been achieved in rectal cancer surgery. Minimal-invasive approaches such as laparoscopic, robotic and transanal-TME (ta-TME) enhance recovery after surgery. Nevertheless, disorders of bowel, anorectal and urogenital function are still common and need attention.

Purpose This review aims at exploring the causes of dysfunction after anterior resection (AR) and the accordingly preventive strategies. Furthermore, the indication for low AR in the light of functional outcome is discussed. The last therapeutic strategies to deal with bowel, anorectal, and urogenital disorders are depicted.

Conclusion Functional disorders after rectal cancer surgery are frequent and underestimated. More evidence is needed to define an indication for non-operative management or local excision as alternatives to AR. The decision for restorative resection should be made in consideration of the relevant risk factors for dysfunction. In the case of restoration, a side-to-end anastomosis should be the preferred anastomotic technique. Further high-evidence clinical studies are required to clarify the benefit of intraoperative neuromonitoring. While the function of ta-TME seems not to be superior to laparoscopy, case-control studies suggest the benefits of robotic TME mainly in terms of preservation of the urogenital function. Low AR syndrome is treated by stool regulation, pelvic floor therapy, and transanal irrigation. There is good evidence for sacral nerve modulation for incontinence after low AR.
\end{abstract}

Keywords Total mesorectal excision $\cdot$ Rectal cancer $\cdot$ Functional outcome $\cdot$ Health related quality of life $\cdot$ Pelvic floor

\section{Introduction}

By the introduction of total mesorectal excision (TME) [1], neoadjuvant chemoradiation (CR) [2,3], improved accuracy of preoperative imaging [4] and better quality assessment of surgical specimens [5], the oncological outcome of rectal cancer surgery has strongly improved. Within a multimodal treatment, a distal resection margin of $\geq 1 \mathrm{~mm}$ may be considered adequate and thus does allow restorative resection even in very low rectal cancer [6-8]. Moreover, several large-scale randomized clinical trials (RCT) have demonstrated the noninferiority regarding the oncological outcome of laparoscopic surgery compared with open surgery for rectal cancer [9-12].

Daniel C. Steinemann

daniel.steinemann@unibas.ch

1 Clarunis, Department of Visceral Surgery, University Centre for Gastrointestinal and Liver Disease, St Clara Hospital and University Hospital, Kleinriehenstrasse 30, 4058 Basel, Switzerland

2 Department of Surgery, University Hospital Basel, Spitalstrasse 23, 4031 Basel, Switzerland
Laparoscopic surgery enables faster recovery with reduced morbidity, reduced surgical site infections, less pain and a shorter hospital stay compared to open surgery [13-16].

Functional outcome and health-related quality of life (HRQOL) after rectal cancer surgery become of everincreasing importance considering improvements in survival. Multimodal treatment of rectal cancer is still associated with an inherent risk of important functionality changes to bowel, anorectal and urinary, as well as sexual function. The incidence of low anterior resection syndrome (LARS) is estimated between 37 and $90 \%$ after rectal resection [17]. Deterioration of function has an important impact on HRQOL.

The goal of this review is to compile different functional changes after rectal cancer treatment. Furthermore, preventive strategies as well as therapeutic options to address the functional deterioration in each domain will be described.

\section{Anorectal and bowel function}

Normal defaecation involves a well-coordinated sequence of events at a semi-voluntary level. Smooth and striated 
muscles, as well as the central, somatic, autonomic and enteric nervous system are required. The rectum serves as a storage reservoir and as a pump for evacuation of faeces. Additionally, the anal canal and the surrounding pelvic floor play an important role during defaecation $[18,19]$. Before defaecation the rectum is mostly empty. Defaecation is initiated by rectal filling and distension. Conscious awareness results in an urge to defaecate as a distension threshold is reached. The contraction of the rectum is followed by relaxation of the internal anal sphincter (IAS) using the recto-anal inhibitory reflex (RAIR). Simultaneously, the external anal sphincter (EAS) is activated to allow rectal contents to move in the upper anal canal to determine the nature of the content. When defaecation is voluntarily allowed the tonic activity of the pelvic floor is inhibited and the puborectal sling is relaxed. EAS is relaxed and by activation of the longitudinal muscles the cushions of the anal canal are flattened. All this is necessary to allow the intrarectal pressure to surpass the pressure of the anal canal. There is a predefaecatory increase in propagatory sequences of motor activity in the rectum. Normal colonic motility includes segmental activity in order to move the faeces slowly distally towards the rectum. There are low amplitude propagated contractions (LAPCs) and high amplitude propagated contractions (HAPCs). HAPC has the function to transport fluid content while LAPC is associated with distension of the viscus and passage of flatus. Furthermore, HAPC plays an important role during defaecation itself. Sleep inhibits colonic motor activity while ingestion of food is a major stimulus [20]. HAPC may precede defaecation but not every HAPC is followed by voluntary defaecation. It has been demonstrated that distension of the sigmoid colon does result in a pressure increase in the rectosigmoid junction limiting the rectal filling [21].

In low anterior resection (LAR) injury causing anorectal and bowel malfunction may occur at different levels (Fig. 1).

\section{Missing rectum}

It is intuitive that rectal dissection results in the loss of a reservoir for stool. Accordingly, a low level of the anastomosis has been identified as a risk factor for the development of LARS in a multi-centre study including 578 patients [22]. Hence, the odds ratio for LARS of TME versus partial mesorectal excision (PME) is 2.81 [23]. Neoadjuvant radiotherapy does further deteriorate the function of the rectal remnant. In a manometry study, 1 year after either LAR alone or CR and LAR not only a decrease in the resting pressure in the latter group was noticed but also a lower rectal compliance [24]. Consistently in a follow-up study, 2 years after external beam radiotherapy for prostate cancer a decrease in rectal capacity and a deterioration of sensory function was found [25].

For the reconstruction of the missing rectum, the mobilized descending colon is pulled down into the pelvis. The colon replacing the rectum is called the "neorectum". Unfortunately, the neorectum does not behave like the rectum. Ziv postulated that loss of rectal activity is associated with the decrease of the analresting pressure. This leads to a change in the pressure gradient between the neorectum and the anal canal. These changes are responsible for faecal soiling [26]. There is evidence for some sensory adaptation within neo-rectal reservoirs. However, poorly compliant neorectum show sensory alteration correlating with incontinence more commonly in patients with preexisting sphincter damage [26, 27]. Koda measured the intracolonic pressure after LAR with a high tie versus a low tie. They could demonstrate a lack of propagating contractions and an increase of spastic motility disorders in the high tie group as well as increased colonic transit time [28]. Spastic hypermotility of the neorectum has been confirmed by others [29]. As a sequela of neuronal damage to the neorectum, an increased postprandial response with high pressure within the neorectum has been observed [30]. Innervation may also be damaged while rectal mobilization or following surgery when inflammation and fibrosis take place resulting in intramural nerve plexus damage [31-34].

\section{Damage to the anus and pelvic floor}

Neurological or structural damage to the IAS leads to passive incontinence (unconscious leakage), whereas injury to the EAS usually results in faecal urgency. IAS damage occurs in up to $18 \%$ due to direct injury by endoanal instrumentation such as the introduction of the stapler device [26, 35]. Even in sigmoid resection with stapled anastomosis, a temporary deterioration of the IAS function has been reported [36, 37]. IAS damage may also result from inter-sphincteric resection (ISR) $[35,38]$.

Moreover, damage to the nerval supply to the IAS occurs from injury to the sympathetic and parasympathetic nerve fibres on the posterolateral side of the prostate [39]. The study by Koda showed that a decrease in the anal canal highpressure zone will lead to severe postoperative defaecatory malfunction [40].

The anorectum is attached to the muscles of the pelvic floor by the conjoint longitudinal muscle. It is activated during defaecation and its contraction induces the shorting of the anal canal. In case of LAR and especially ISR, the anorectum is detached from the pelvic floor thus leading to deterioration of defaecation $[41,42]$. 


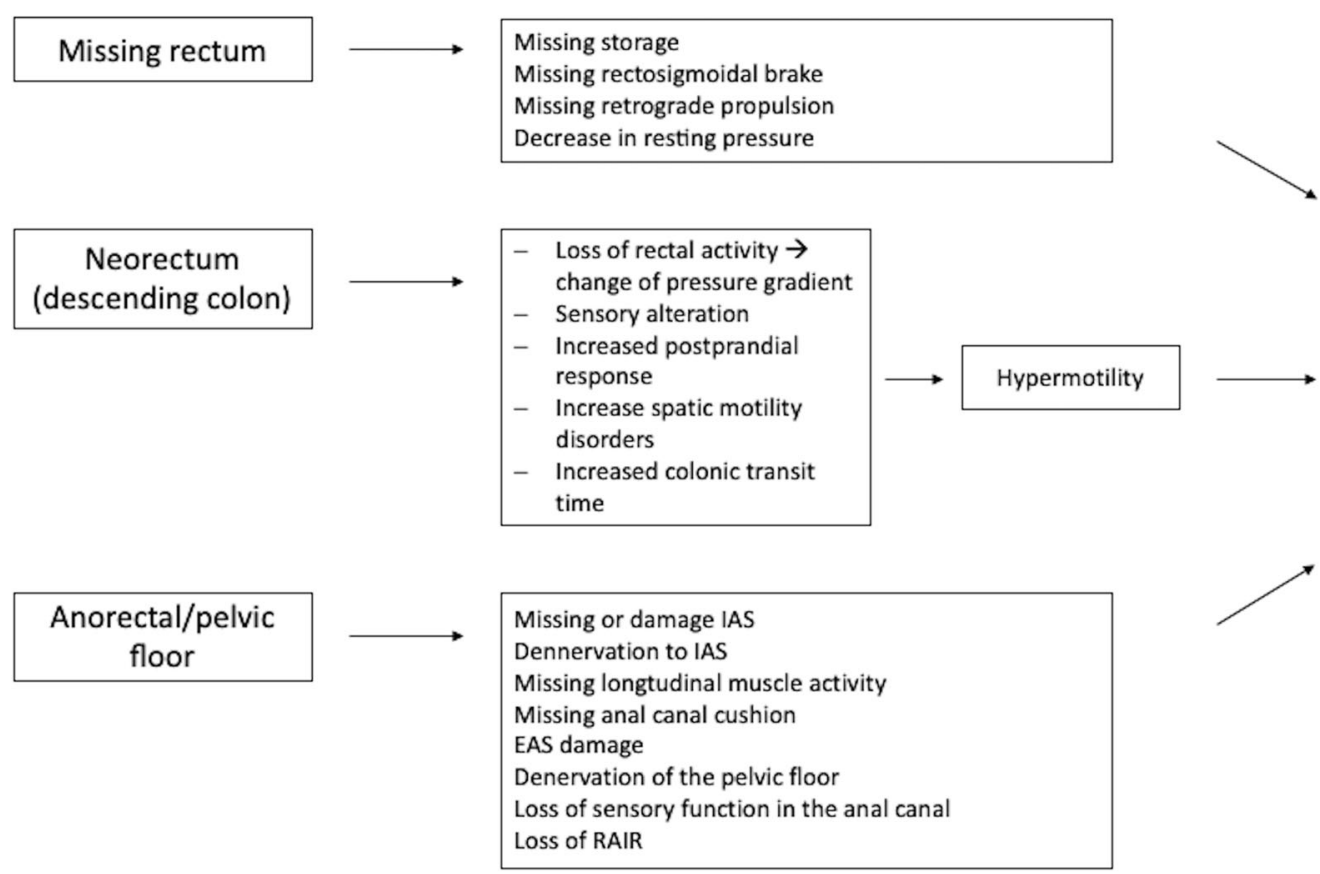

Increased bowel movements

Deterioration of defecation

Faecal urgency

Urge incontinence

Passive incontinence

Clustering

Evacuation difficulties

Fig. 1 Injury levels, anorectal and bowel dysfunctions and subsequent symptoms after anterior resection (AR)

\section{Incidence and assessment of low anterior resection syndrome}

Major LARS occurs in 37 to $90 \%$ of patients after LAR [43-47]. Severe incontinence is prevalent in ultralow anterior resection (AR) in $49 \%$ and in ISR even in 76\% [48]. Previously the symptoms were thought to be transient, mainly resolving by 12 months after AR [49]. However, several long-term studies are now reporting the presence of symptoms up to 15 years after AR, with the prevalence of faecal incontinence varying from 0 to $71 \%$ and rectal evacuation disorders from 12 to $74 \%[50,51]$. Furthermore, a recent meta-analysis showed that the estimated long-term prevalence of majors LARS after rectal cancer surgery was $41 \%$ [52]. These results indicate that this syndrome is not a transient irritability of the neorectum in the postoperative period, but a result of permanent changes [17].

The LARS score is a valid and reliable score correlated to HRQOL. The range is divided into 0 to 20 (no LARS), 21 to 29 (minor LARS) and 30 to 42 (major LARS) [53]. Patients with LARS fall into two groups: those with urgency or faecal incontinence and those with evacuation dysfunction, although symptoms often overlap [17].

However, LARS is not specific for AR. Major LARS in the age group 50 to 79 years are reported in 10 to $19 \%$ of the general population $[54,55]$. Furthermore, in a Swedish prospective study, major LARS was found in $20 \%$ after right colonic resection and $16 \%$ after left colonic resection [56].

The Rockwood scale, the St. Mark's incontinence score, the Memorial Sloan-Kettering Cancer Centre Bowel Function Instrument system (MSKCC BFI), the Wexner score and the abovementioned LARS score are the most commonly used tools assessing faecal incontinence [53,57-61].

\section{Prevention of low anterior resection syndrome}

\section{Non-operative management}

Considering the important changes in bowel function and the associated deterioration of HRQOL the indication for LAR is questioned in patients with early rectal cancer as well as patients with clinical complete remission after neoadjuvant $\mathrm{CR}$ [62].

After neoadjuvant $\mathrm{CR}$ in 8 to $27 \%$, a complete pathological response is achieved [63-65]. An alternative approach in patients with a complete response is nonoperative management (NOM). Most patients with NOM may avoid surgery and a definitive colostomy with reasonable anorectal and urinary function [66]. The matched controlled study by Hupkens et al. showed a better HRQOL, better physical and emotional rates and better global health status after NOM compared to LAR. These patients had also fewer problems with defaecation and sexual and urinary tract function. However, CR therapy on its own is not without long-term side effects. One-third of the NOM patients experience major LARS symptoms, as compared with $67 \%$ of the patients after TME [67]. The metaanalysis of Dossa et al. including 867 patients demonstrated that most patients within NOM avoid major surgery with a similar survival rate compared with LAR. Nevertheless, there is a lack of a high level of evidence studies [68]. NOM is associated with an inherent higher local recurrence rate but not a worse overall survival. Given the very low level of evidence, NOM should only be considered within studies [69]. 
Local excision by transanal endoscopic microsurgery (TEM) should be considered in low-risk T1 cancers [70]. In the CARTS study, 55 patients with a median age of 64 years with T1-3 N0 (EMVI-, G1-2, V0, L0) rectal cancer were evaluated for CR followed by TEM. Of those, $85 \%$ underwent TEM after achieved downsizing. Four patients (9\%) developed local recurrence within 12 months and underwent salvage TME. The 5-year disease-free survival was $81.6 \%$. However, three of four patients with local recurrence also developed distant metastasis and died. Moreover, another 4 patients had metachronous distant metastasis. Of the patients undergoing organ-preserving therapy $50 \%$ had major LARS 48 to 68 months after treatment [71]. In the GRECCAR 2 trial 148 patients with cT2-3 low rectal cancer and downsizing after chemoradiation (residual tumour $<2 \mathrm{~cm}$ ) were randomly assigned to TEM or TME. Completion TME was performed in 26 patients of the TEM group in the case of ypT2-3. The two-year local recurrence rate was $5 \%$ in the TEM and $6 \%$ in the TME group $(p=0.68)$ and the disease-free survival $78 \%$ and $76 \%(p=0.45)$. The incidence of faecal incontinence was $5 \%$ and $14 \%(p=0.34)$ and the rate of sexual dysfunction $23 \%$ and $18 \%(p=0.81)$ [72]. The failure to demonstrate a superior functional outcome in the TEM group was explained by the high rate of completion TME. The ongoing GRECCAR 12 trial will investigate the outcome with more restrictive indications for completion TME (only ypT3 or ypT3cN+ or R1) and with the inclusion of neoadjuvant induction chemotherapy. Currently, local excision in $>$ pT1 low-risk cancer should only be considered within clinical trials or in frail patients.

\section{No radiotherapy}

The high level of anorectal and bowel dysfunction in NOM demonstrates that CR alone contributes importantly to LARS. $[57,73-75]$. The study by Lange et al. showed that 5 years after surgery faecal incontinence occurred in $62 \%$ of patients who had preoperative radiotherapy and only in $39 \%$ of patients who had not [76]. Another recent study performed in England showed that patients who received preoperative radiation therapy had higher odds of reporting disturbed bowel control (OR 1.55), severe urinary leakage (OR 1.69) and sexual difficulties (OR 1.73) compared with those who had surgery alone. In addition, patients who received long-course $\mathrm{CR}$ reported better bowel control than those who had short-course radiation therapy [77]. The 15-year's results of an RCT of preoperative short-course radiotherapy followed by TME versus TME alone showed worse functional results for the first group in terms of faecal incontinence $(12 / 21$ vs. $11 / 42, p=$ $0.01)$ and urinary incontinence $(45 \%$ vs $27 \% ; p=0.02)$ [78]. The use of pads for faecal incontinence is increased for preoperative CR vs TME alone 5 years after treatment ( $51.5 \%$ vs. $30.5 \%$ ) [79]. Neoadjuvant CR is beneficial and recommended in stage II and III rectal cancer [63]. However, in cT3a and
cT3b (invasion of the mesorectum $<5 \mathrm{~mm}$ ) cN0, EMVIcancers the omission of neoadjuvant radiation may be considered assuming a local recurrence rate similar to stage I cancer in this specific subset of patients $[80,81]$.

\section{No restoration}

No difference in the general HRQOL comparing AR and abdominoperineal resection (APR) was found in a metaanalysis including 1443 patients [82]. The decision whether to perform APR or AR should-beside oncological considerations - include an assessment of the anticipated bowel function. The preoperative LARS score (POLARS) is a nomogram that allows the estimation of postoperative bowel function. Predictive factors included in the POLARS score are tumour height, age, TME vs. PME, protective defunctioning stoma and preoperative radiotherapy [83]. Further factors to be considered in the decision-making should be co-morbidities, preoperative continence and sphincter function as well as cognition, coping, lifestyle and expectations of the patient. In a study, patients were asked prior to surgery for their choice. While 30\% opted for AR only 5\% decided for APR but $65 \%$ chose to leave the decision to the surgeon. Four years after, surgery patients were asked again how they would choose if they could decide again. Of the APR patients, $46 \%$ would choose again for APR, but $22 \%$ for AR, $32 \%$ would leave the decision to the surgeon. Of the AR patients, $69 \%$ would again decide for AR and only $4 \%$ for APR. The remaining $28 \%$ leave the decision to the surgeon. The sequela of AR seems to be more acceptable than those of APR [84]. These findings underline the importance to involve the patient in this important decision prior to surgery.

\section{Partial versus total mesorectal excision}

As previously discussed, the height of anastomosis plays an important role in the risk of developing LARS. Coloanal anastomosis showed the absence of recto-anal inhibitory reflex (RAIR), which is replaced by a sharp contraction, and a lower anal resting pressure when compared with controls. The absence of RAIR is the consequence of the complete excision of the rectum such as in ultralow AR with coloanal anastomosis. RAIR recovers in most cases by the end of the second postoperative year, but the coordinated sensory-motor integration of the rectum remains distorted. Conclusively, the lower the resection is performed, the more functional complications may occur $[28,30,34,85,86]$.

TME is a risk factor to develop LARS. Bregendahl et al. who analysed functional outcomes after curative resection for rectal cancer showed a higher risk of developing a major LARS after TME as compared to PME (OR $=0.21)$ [57]. In tumours of the upper rectum, a distal resection margin of $5 \mathrm{~cm}$ is sufficient. Within the mesorectum, tumour spreads are 
found up to $40 \mathrm{~mm}$ distal from the tumour. In tumours located more than $10 \mathrm{~cm}$ from anal verge, a PME should be performed to avoid unnecessary deterioration of bowel function.

\section{Technique of anastomosis}

Reduced neorectal reservoir volume, resulting from the construction of a conventional end-to-end anastomosis is presumed to be the cause of urgency and incontinence and has led to develop alternative configurations. Colonic J-pouch, transverse colosplasty and side-to-end anastomosis have a similar outcome in terms of frequency, urgency, continence, evacuation function and HRQOL (Table 1). For the ease of construction, side-to-end anastomosis should be the preferred reconstruction.

Regarding the performance of anastomosis, a metaanalysis analysing functional outcomes of stapled versus hand-sewn ileal pouch-anal anastomosis (IPAA) following proctocolectomy in ulcerative colitis showed that stapled IPAA offered improved nocturnal continence [99]. Similarly, the incidence of severe or moderate incontinence 36 months after ultralow AR with hand-sewn coloanal anastomosis versus double stapling LAR was $94.2 \%$ and $38.8 \%$ in a large observational study [98].

\section{Surgical technique (laparoscopy, robotic, taTME)}

It has been questioned whether anorectal function might be worse in patients who received a temporary stoma in LAR. In a Swedish RCT 234, patients were randomly assigned to receive a defunctioning stoma or not for
LAR with an anastomosis $<7 \mathrm{~cm}$ from the anal verge. The rate of symptomatic anastomotic insufficiency did largely differ $(10.3 \%$ vs $28 \%, p<0.0001)$ [100]. In the 12 -year follow-up 46 with and 41 without initial temporary stoma were available for a functional follow-up. The rate of patients experiencing a symptomatic anastomotic insufficiency did not differ in the groups of followed patients. Increased rates of incontinence for flatus ( $p=$ $0.03)$, and liquid stool $(p=0.005)$ but not for major LARS were found in the stoma group [46]. However, it should be noted that in the initial trial more patients in the stoma group had preoperative radiotherapy [100]. This difference was no longer significant in the 12-year follow-up (93\% in the stoma group, $80 \%$ in the no stoma group); but the sample size might be too small to detect a difference [46]. In a retrospective analysis of $150 \mathrm{LAR}$ patients, the multivariate analysis showed that the creation of protective stoma and the time to ileostomy closure were not risk factors for LARS [101]. However, in an RCT comparing early (8-13 d) and late (>12 weeks) ileostomy closure no difference in major LARS $(29 / 40$ and 25/42, $p=0.25$ ) was found but worse scores for soiling were detected in the late closure group ( $p=$ 0.017) [102].

Regarding HRQOL, RCTs showed conflicting results comparing laparoscopic and open surgery. There is a lack of studies comparing laparoscopic and open LAR concerning the functional outcome. A few case-control studies compare transanal TME (ta-TME) and laparoscopic TME. They demonstrate comparable outcomes or even worse functional results for ta-TME. In case-control
Table 1 Studies evaluating the technique of anastomosis in anterior resection (AR) for rectal cancer surgery

\begin{tabular}{llll}
\hline Recommendation/results & Design & Evidence* & Reference \\
\hline $\begin{array}{l}\text { Reduced defaecation frequency and urgency in J-pouch and transverse } \\
\text { coloplasty compared to straight anastomosis }\end{array}$ & MA & 2a & {$[87]$} \\
$\begin{array}{l}\text { Fewer evacuation disorders after transverse coloplasty compared to } \\
\text { J-pouch }\end{array}$ & RCT & $1 \mathrm{~b}$ & {$[88-90]$} \\
$\begin{array}{l}\text { J-pouch has similar surgical and functional results as side-to-end anasto- } \\
\text { mosis whereas transverse coloplasty has no advantage }\end{array}$ & RCT & $1 \mathrm{~b}$ & {$[91-93]$} \\
$\begin{array}{l}\text { J-pouch, side-to-end anastomosis and transverse coloplasty lead to better } \\
\text { functional outcomes compared to straight anastomosis }\end{array}$ & MA & $2 \mathrm{a}$ & {$[94]$} \\
$\begin{array}{l}\text { Comparable HRQOL, functional outcomes and complications rates one } \\
\text { and two years after J-pouch or side-to-end anastomosis }\end{array}$ & RCT & $1 \mathrm{~b}$ & {$[96]$} \\
$\begin{array}{l}\text { No difference in terms of evacuation and incontinence scores 6, 18 and } \\
\text { 24 months postoperatively comparing side-to-end anastomosis, } \\
\text { straight anastomosis and J-pouch }\end{array}$ & RCT & $1 \mathrm{~b}$ & {$[97]$} \\
$\begin{array}{l}\text { Incidence of severe or moderate incontinence 36 months after ultralow } \\
\text { AR; hand-sewn 94.2\% vs. double stapling 38.8\% }\end{array}$ & POS & $3 \mathrm{~b}$ & {$[98]$} \\
$\begin{array}{l}\text { No difference in evacuation function 12 months after surgery in J-pouch } \\
\text { vs. side-to-end anastomosis }\end{array}$ & RCT & $1 \mathrm{~b}$ \\
\hline
\end{tabular}

$M A$, meta-analysis; $R C T$, randomized controlled trial; $S R$, systematic review; $P O S$, prospective observational study

*Level of evidence (March 2009) _ Oxford Centre for Evidence-based Medicine 
studies, robotic LAR was found to be beneficial in terms of urogenital function preservation. However, no difference for LARS was demonstrated (Table 2).

\section{Intraoperative neuromonitoring}

A prophylactic approach to avoid nerve damage and the associated deterioration of functional outcomes is intraoperative neuromonitoring (IONM). Kneist et al. conducted a prospective study with a small group of patients undergoing LAR with IONM through pelvic splanchnic nerve stimulation under continuous electromyography of the IAS. The study showed that all patients with positive IONM signals were continent after stoma closure [120]. A consecutive casecontrol series by the same researchers demonstrated a significant lower rate of urinary and anorectal dysfunction after using IONM [121]. In addition, the laparoscopic neuromapping seems to be an appropriate method for reliable quality assurance of laparoscopic nerve-sparing surgery [122]. Kauff et al. compared pelvic IONM during TME with a control group and demonstrated the less new onset of faecal incontinence in the neuromonitoring group at each follow-up (3, 6. 12 and 24 months) [123]. Zhou et al. demonstrated no difference between preoperative and postoperative urogenital and anorectal function in patients with positive IONM. Those patients exhibited higher International Prostate Symptom Score, a lower IIEF-F and a lower Female Sexual Function Index score 12 months postoperative compared with patients with negative IONM [124]. The ongoing NEUROS RCT by Kauff et al. will hopefully provide high-quality evidence on the efficacy of pelvic IONM aiming for the improvement of functional outcome in rectal cancer patients undergoing TME [125].

\section{Therapy of anorectal and bowel disorders}

\section{Pharmacological therapy}

There are a few studies regarding treatment for LARS. For diarrhoea-predominant LARS with incontinence for liquid stool and in case of increased frequency, loperamide is used. Loperamide increases sphincter resting pressure by $20 \%$. Reduced bowel frequency and improved nighttime continence are reported [126]. Good results are experienced with managing incontinence and clustering with psyllium. In a cross-over study in incontinent patients, both loperamide and psyllium were equally effective, whereas less unwanted constipation occurred with psyllium [127].
Table 2 Studies evaluating the open, laparoscopic, robotic and transanal surgical technique for rectal cancer

\begin{tabular}{|c|c|c|c|}
\hline Recommendation/results & Design & Evidence* & Reference \\
\hline \multicolumn{4}{|l|}{ Laparoscopic vs. open technique } \\
\hline $\begin{array}{l}\text { Better scores in HRQOL and less defaecation problems in laparoscopic } \\
\text { vs. open AR }\end{array}$ & $\mathrm{RCT}$ & $1 \mathrm{~b}$ & {$[103]$} \\
\hline $\begin{array}{l}\text { No differences in HRQOL in 12-month follow-up laparoscopic vs open } \\
\text { AR }\end{array}$ & $\mathrm{RCT}$ & $1 b$ & {$[104]$} \\
\hline \multicolumn{4}{|l|}{ Transanal TME (taTME) vs. laparoscopic TME } \\
\hline \multirow{2}{*}{$\begin{array}{l}\text { Better oncological and functional results, comparable pathological } \\
\text { results, acceptable short-term postoperative outcomes, shorter opera- } \\
\text { tion time, less blood loss and shorter hospital stay after taTME vs } \\
\text { laparoscopic }\end{array}$} & $\mathrm{CS}$ & $3 b$ & {$[105-107]$} \\
\hline & MA & $3 a$ & {$[108]$} \\
\hline \multirow[t]{2}{*}{ Comparable functional outcomes taTME comparing with laparoscopy } & $\mathrm{CS}$ & $3 b$ & {$[109-111]$} \\
\hline & MA & $3 \mathrm{a}$ & [112] \\
\hline $\begin{array}{l}\text { Higher anorectal dysfunction in taTME compared to laparoscopic } \\
\text { including buttock pain, diarrhoea, clustering of stools and urgency }\end{array}$ & $\mathrm{CS}$ & $3 b$ & [113] \\
\hline \multicolumn{4}{|l|}{ Robotic vs. laparoscopic technique } \\
\hline $\begin{array}{l}\text { Earlier recovery of voiding and sexual function after robotic TME vs } \\
\text { laparoscopic }\end{array}$ & $\mathrm{CS}$ & $3 b$ & {$[114-116]$} \\
\hline $\begin{array}{l}\text { Robot-assisted surgery may be technically more efficient, especially in } \\
\text { low-lying tumours requiring inter-sphincteric resection and complex } \\
\text { pelvic dissection }\end{array}$ & $\mathrm{CS}$ & 4 & {$[117]$} \\
\hline $\begin{array}{l}\text { Robotic and laparoscopic inter-sphincteric resection show comparable } \\
\text { results }\end{array}$ & MA & $3 a$ & {$[118]$} \\
\hline \multicolumn{4}{|l|}{ Benefits of robotic ISR should be evaluated in larger RCTs } \\
\hline No difference in major LARS between laparoscopic and robotic TME & RCT & $1 \mathrm{~b}$ & [119] \\
\hline
\end{tabular}

$M A$, meta-analysis; $R C T$, randomized controlled trial; $P O S$, prospective observational study; $E S$, evaluation study; $C S$, comparative study

*Level of evidence (March 2009) — Oxford Centre for Evidence-based Medicine 
Itagaki et al. showed the effectiveness of serotonin receptor antagonists (5-HT3) for the treatment of LARS, as in diarrhoea-predominant irritable bowel syndrome. Functional outcomes improved after taking ramosetron for 1 month [128]. 5-HT3 are effective because of their ability to slow gut transit. Especially in patients with postprandial urgency due to increased propagatory propulsions in the neorectum 5-TH3 antagonists have been shown to be effective. [129].

Increased flatulence and bloating may be associated with small intestinal bacterial growth (SIBO). SIBO is treated with antibiotics such as rifaximin and neomycin [130]. Stephens et al. failed to demonstrate any difference in bowel function in patients randomly assigned to placebo or probiotics after the reversal of a temporary loop ileostomy as a result of prior rectal resection [131].

\section{Pelvic floor rehabilitation}

Pelvic floor rehabilitation (PFR) includes pelvic floor muscle training (PFMT), biofeedback (BF) and rectal balloon training (RBT) and is accepted treatment for faecal incontinence. PFMT improves the structural support, the timing and strength of automatic contractions resulting in reduced leakage. BF uses visual and hearing signals to inform patients about internal physiological events. This therapy leads to a more precise discrimination of rectal sensation and synchronise voluntary contraction of the EAS as a response to rectal sensation. The RBT has the aim to improve rectal sensitivity by stepwise reductions in rectal balloon distension, in order to learn to distinguish smaller rectal volumes. In case to resist urgency, a progressive distension is performed or it can be used to counteract the RAIR by using the voluntary anal squeeze [132]. A systemic review, an RCT, and a few case-control studies demonstrated a reduction in incontinence scores, reduced stool frequency, and improved HRQOL (Table 3).

\section{Transanal irrigation}

In a subgroup of patients with LARS, a positive effect of transanal irrigation (TAI) was noted (Table 4). However, only a third of patients with TAI are willing to continue this therapy $[139,140]$. During TAI the LARS score dropped from 35 to 12 after 6 months but rose to 273 months after the suspension of TAI in a study of Martelucci et al. [142]. When TAI is discontinued there seems to be no sustained improvement in LARS.

\section{Sacral neuromodulation}

Sacral nerve modulation (SNM) has proven to be effective in several small studies [143-151]. A meta-analysis showed a reduction of the frequency of weekly episodes of incontinence and an improvement of the ability to defer defaecation [150].
After device implantation, the mean incontinence score decreased, and the mean number of incontinence episodes dropped. Manometric parameters were consistent with clinical results: maximum and mean resting tone and the squeeze pressure were normal in the patients with improved incontinence symptoms [143]. Miguel et al. demonstrated a reduction in the Cleveland Clinic Florida Faecal Incontinence scoring system (CCF-FI) after device implantation as compared to preimplantation [144]. Ramage et al. reviewed the literature in 2015 [149]. Of the patients, $79.1 \%$ proceeded to permanent SNM implantation. In five studies, the main factor to proceed with permanent implementation was a peripheral nerve evaluation threshold of more than 50 to $70 \%$ symptom improvements [143-145, 147, 151]. Furthermore, reduction of nocturnal defaecation, fragmentation, urgency and soiling in twothirds of the patients after implantation of SNM were reported [148]. The mean Wexner score was significantly reduced from 17.7 to 4.6 and the mean LARS score from 36.9 to 11.4 [149]. Interestingly overall efficacy of SNM is comparable with results found after SNM for other causes of faecal incontinence. SNM has been shown to be effective in LAR patients after neoadjuvant $\mathrm{CR}$ with a sustained reduction of incontinence scores and an increase in HRQOL [148]. In another retrospective series of incontinence predominant LARS patients, the permanent implantation rate of SNM was $70 \%$ with an improvement in incontinence scores up to 5 years after implantation [152]. In a systematic review of Ram et al., 114 patients with SNM in the context of LARS were identified. The overall success rate was $83 \%$ with sustained improvement of HRQOL [153]. Huang et al. found a mean reduction in LARS of 17.8 points by SNM in their meta-analysis [154]. D'Hondt et al. analysed 11 patients undergoing SNM for LARS and found an amelioration not only in incontinence but also reduced clustering, reduced bowel movements and reduced urgency [155].

Another therapeutic approach is tibial nerve stimulation, which could be divided into two forms; percutaneous (PTNS) and transcutaneous (TTNS). PTNS and TTNS seem to improve in some outcome measures, but TTNS was not superior to sham stimulation in a large powered RCT [156]. PTNS consists of the insertion of two small electrodes above the medial malleolus adjacent to the posterior tibial nerve and another placed under the arch of the foot. Both electrodes are connected to the neurostimulator in general for $30 \mathrm{~min}$ in one procedure. The CONFIDENT-study as a large double-blind, multicentre RCT found no significant benefit of PTNS over sham electrical stimulation [157].

\section{Urogenital function}

Sympathetic and parasympathetic nerves of the superior and inferior hypogastric plexus control bladder and sexual function. Sympathetic nerves are responsible for male and probably female ejaculation, while parasympathetic nerves cause 
Table 3 Studies evaluating pelvic floor rehabilitation (PFR) for low anterior resection syndrome (LARS)

\begin{tabular}{|c|c|c|c|}
\hline Recommendation/results & Design & Evidence* & Reference \\
\hline Incontinence score was improved after pelvic floor rehabilitation & SR & $2 \mathrm{a}$ & [133] \\
\hline $\begin{array}{l}\text { Lower mean stool frequency in patients after sphincter training compared } \\
\text { without training }\end{array}$ & $\mathrm{CS}$ & 4 & [134] \\
\hline \multicolumn{4}{|l|}{ Both groups similar continence score (Wexner score 8.3 vs. 9.9) } \\
\hline \multicolumn{4}{|l|}{ Less dyschezia and improved HRQOL after training } \\
\hline $\begin{array}{l}\text { Positive short- and long-term effects of pelvic floor rehabilitation and } \\
\text { biofeedback training in patients with faecal incontinence after surgery } \\
\text { plus CR and in patients with surgery alone }\end{array}$ & $\mathrm{CS}$ & $2 b$ & {$[135]$} \\
\hline \multicolumn{4}{|l|}{ Increase in modified Cleveland Incontinence Score } \\
\hline $\begin{array}{l}\text { Improvement of Wexner score, number of bowel movements and } \\
\text { anorectal manometry after biofeedback training in patients with LARS }\end{array}$ & CS & 4 & {$[136]$} \\
\hline $\begin{array}{l}\text { Rectal balloon training with pelvic floor muscle training is equally } \\
\text { effective as pelvic floor muscle training alone }\end{array}$ & RCT & $1 b$ & {$[132]$} \\
\hline $\begin{array}{l}\text { Beneficial effect of rectal balloon training on urgency control, global } \\
\text { perceived effect and lifestyle adaptations }\end{array}$ & & & \\
\hline
\end{tabular}

erection, lubrication and swelling of the labia and the clitoris [158]. Sexual disorders may occur postoperatively for multiple reasons [159]. Among women sexual dysfunction may occur due to fatigue, depression, loss of independence and changes in relationships [160]. For men, there is also a relation to age [161]. In male patients, a diminished erection and ejaculation may be due to damage to the inferior hypogastric plexus on one side. Damage on both sides leads to impotence and bladder denervation. Retrograde ejaculation occurs when superior hypogastric plexus and/or the hypogastric nerve on both sides are damaged [162-164], whereas damage to both sides of the inferior hypogastric plexus results in female dyspareunia, decreased ability to reach orgasm, arousal and diminished vaginal lubrication may arise by unilateral injury of the inferior hypogastric plexus [163]. The main cause of postoperative sexual dysfunction is an intraoperative injury to the neurovascular bundles [165]. Leaving the Denonvilliers' fascia intact on the prostate side during the anterior rectal dissection is mandatory to preserve these autonomic fibres. An exception to this rule are advanced tumours located on the anterior aspect of the rectum [166].

Focusing on the bladder function parasympathetic nerves control the detrusor muscle, the relaxation of the urethra and inhibit the nerve activity of the external urethral sphincter, while the sympathetic nerves control the urinary continence [158, 167]. Direct nerve damage happens during the mobilisation or traction of the rectum and might be an explanation for the improvement of the voiding dysfunction in
Table 4 Studies evaluating transanal irrigation (TAI) for low anterior resection syndrome (LARS)

\begin{tabular}{|c|c|c|c|}
\hline Recommendation/results & Design & Evidence* & Reference \\
\hline $\begin{array}{l}\text { Fewer complaints of constipation, less faecal incontinence, improved } \\
\text { HRQOL after TAI compared to best supportive care }\end{array}$ & $\mathrm{CS}$ & 4 & $\begin{array}{l}{[137,} \\
138]\end{array}$ \\
\hline $\begin{array}{l}\text { Effect of } 79 \% \text { to } 100 \% \text { after TAI in patients with defaecation disturbances } \\
\text { after pouch surgery or LAR }\end{array}$ & SR & $3 a$ & $\begin{array}{l}{[139,} \\
140]\end{array}$ \\
\hline \multicolumn{4}{|l|}{$1 / 3$ of the patients are willing to continue } \\
\hline \multicolumn{4}{|l|}{ Perforation rate of sigmoid colon or rectum is $0.002 \%$} \\
\hline $\begin{array}{l}\text { Decrease of number of defaecations during the day and night, Cleveland } \\
\text { incontinence score decreased, the mental component of SF36 and all } \\
\text { domains of the Rockwood QoL instrument improved }\end{array}$ & $\mathrm{CS}$ & 4 & {$[141]$} \\
\hline Decrease number of median daily bowel movements after TAI & $\mathrm{CS}$ & 4 & {$[142]$} \\
\hline \multicolumn{4}{|l|}{$\begin{array}{l}\text { LARS score dropped from } 35.1 \text { to } 12.2 \text { after } 6 \text { months but rose to } 27 \\
3 \text { months }\end{array}$} \\
\hline $\begin{array}{l}\text { Four components of the SF- } 36 \text { improved during the TAI period and the } \\
\text { MSKCC BDI score significantly improved in several domains }\end{array}$ & & & \\
\hline
\end{tabular}

$S R$, systematic review; $C S$, comparative study

*Level of evidence (March 2009) — Oxford Centre for Evidence-based Medicine 
many patients months after operation [167, 168]. Inflammation in the perivesical tissues, altered anatomy, immobilisation, failure of perineal relaxation caused by pain, failure to open the bladder neck due to stress-induced sympathetic over-activity, bladder distension and reduced contractility could all be additional indirect causes of urinary dysfunction [167]. Furthermore, adjuvant radiation therapy causes fibrosis of the bladder and urethral sphincters, which negatively affects the bladder function $[169,170]$.

The most common symptom in bladder dysfunction after rectal cancer surgery besides stress incontinence and urgency is the difficulty of emptying the bladder. Damage to inferior hypogastric nerve plexus leads to emptying failure, especially when performed on both sides [162-164]. Early postoperative urinary catheter removal decreases urinary tract infections rate, accelerates patient mobilisation and decreases length of stay. Nevertheless, the exact timing of the removal remains unclear $[171,172]$. There is one ongoing RCT aiming to determine the optimal time slot for urinary catheter removal after laparoscopic AR [173]. Lange et al. showed an improvement of emptying dysfunction after 3 months, whereas symptoms that last up to 6 months seem to be permanent. Long-term dysfunction is reported by $31 \%$ of patients [167].

\section{Incidence and assessment of urogenital dysfunction}

A high percentage of patients experience new sexual dysfunction and discontinue sexual activity posttreatment [174-176]. A large number of studies have focused on bowel dysfunction only. In comparison, there is far less information about urinary and sexual dysfunction. More than half of the patients experience a deterioration in sexual function, consisting of ejaculatory problems and impotence in men and vaginal dryness and dyspareunia in women $[177,178]$.

Urinary dysfunction occurs in one-third of patients treated for rectal cancer due to surgical nerve damage [158, 177]. Toritani et al. observed urinary dysfunction in $8.8 \%$ of the patients after autonomic nerve-preserving surgery for rectal cancer. A multivariate analysis showed that tumour location in the lower rectum, tumour diameter $>39 \mathrm{~mm}$, operation time $>239 \mathrm{~min}$, blood loss $>299 \mathrm{ml}$ and diabetes were independent risk factors of urinary dysfunction [179]. The incidence of postoperative urinary retention is reported in up to $18.5 \%$. [180].

The International Prostate Symptom Score (IPSS) and Bristol female lower urinary tract symptom (BFLUTS) questionnaire are the most internationally validated scores and have been used most widely for assessing urinary dysfunction in male and women [181, 182]. The International Index of Erectile Function (IIEF) and the Female Sexual Function Index (FSFI) questionnaire are the most widely used and internationally recognised and validated tools for assessing male and female sexual dysfunction [183, 184]. Other self-made questionnaires should no longer be used. The IIEF is limited by the superficial assessment of the psychosexual background and assessment of the partner relationship, both important factors for sexual dysfunction. Another recently validated score is the Sexual Functional Vaginal Changes questionnaire. The score includes 7 items with a range of 0 to 29 points. A score $>8$ indicates a sexual dysfunction and has a sensitivity of $76 \%$ and specificity of $75 \%$ detecting patients bothered by sexual dysfunction with a negative impact on HRQOL [185].

\section{Prevention of dysfunction}

Effective therapeutic modalities for patients with urinary dysfunction after rectal cancer treatment are missing. The best therapy remains prevention. The identification and preservation of pelvic nerves is of utmost importance. IONM showed improved functional results in some studies [120-125, 186]. IONM exhibited a higher International Prostate Symptom Score, a lower IIEF-F and a lower Female Sexual Function Index score at 12 months postoperatively [124].

In the HIGHLOW trial, 214 patients were randomised to a high or low tie of the inferior mesenteric artery in laparoscopic LAR. Patients in the low tie group reported better urinary continence, less obstructive urinary symptoms and better sexual functioning 9 months after surgery [187].

Laparoscopic surgery gained acceptance for better functional outcomes. Surprisingly, the first laparoscopic results have shown a higher prevalence of male sexual dysfunction, but not in urinary disorders compared to open surgery. Later better results were reported [188-192]. Another RCT showed no difference in sexual dysfunction and micturition symptoms after laparoscopic versus open AR [193].

After robotic TME earlier recovery of voiding and sexual function due to more precise dissection compared to laparoscopy has been demonstrated $[114,115,194]$. A recently published retrospective cohort by Yamaoka showed an inversely correlation of robotic AR with postoperative early urinary dysfunction [195]. Moreover, the systematic review by Broholm et al. presented improved urogenital function results after robotic AR compared to laparoscopy [196]. So did another recent meta-analysis, which showed better bladder function after 12 months and better sexual function after 3 months in the robotic group compared with laparoscopy [197]. Improved sexual functioning has been observed in an RCT comparing robotic and laparoscopic TME $(p=0.032)$ [198]. On the other hand, Celentano et al. state that there is no evidence to date in favor of any surgical approach concerning sexual results [199].

\section{Therapy of urogenital disorders}

Partial nerve damage occurs often but may improve and resolve 6 months postoperatively. Erectile dysfunction has been 
noted to return within 6-12 months after nerve injury. However, therapy should be started as early as possible because delayed treatment may lead to permanent dysfunction [200]. Psychotherapeutic help is important regarding psychological, emotional or social factors. It helps to regain the corporal image. Another therapeutic approach is a medication with sildenafil. Nishizawa et al. showed a satisfactory improvement of $69 \%$ of male patients with erectile dysfunction after LAR [201]. As an alternative, urdenafil with $85 \%$ satisfactory improvement was described [202]. Only after drug therapy failed, physical treatments, either with intracavernosal injection or implanted silicone rods, inflatable penile implants and vacuum devices are available [201-203]. In women, management is based on sex therapy and psychotherapy, especially for libido disorders. For vaginal atrophy and dryness topical oestrogen is recommended [204].

Diversionary or occlusive devices and absorptive incontinence pads or undergarments are available for long-term urinary incontinence. Patients with compliance abnormalities (failure to store) may be treated with a combination of medication and surgery. Anticholinergic medications may decrease the pressure within the bladder during storage as well as marginally increase bladder volumes. As an alternative, the use of SNM for the refractory overactive bladder may be considered [203]. Furthermore, repeated injection of botulinum toxin in the detrusor muscles in patients with refractory detrusor over-activity show acceptable results $[205,206]$.

\section{Conclusion}

In conclusion, several considerations are to be made to prevent dysfunction after rectal cancer surgery. The indication for TME should be decided at a multidisciplinary tumour conference and well balanced against NOM or local excision. Further multicentre RCTs are needed in order to define the indications for neoadjuvant radiotherapy more accurate as $\mathrm{CR}$ largely contributes to LARS. For tumours of the upper rectum, PME should be preferred. If possible, a low tie of the inferior mesenteric artery should be performed. The decision for restoration versus APR should be based on a formal assessment including POLARS and all relevant factors must be included. If restoration is decided, side-to-end anastomosis in a doublestapling technique seems to be the best anastomotic technique. The performance of an ileostomy does not increase the risk for later LARS, but the role of timing of stoma closure is still unclear. Further high-evidence clinical studies are required to clarify the benefit of IONM and to assess the functional outcome of robotic versus laparoscopic AR and ta-TME.

Concerning the therapy loperamide, psyllium, as well as 5HT3 antagonists are proven to have some effect on LARS. A cornerstone in therapy of LARS is furthermore PFR including $\mathrm{BF}$. There seems to be evidence for the use of TAI and for SNM to treat incontinence and clustering. In case of bladder dysfunction and sexual dysfunction, patients should be referred early to urology. A proposal of a diagnostic and therapeutic algorithm for dysfunction after AR is depicted in Fig. 2.
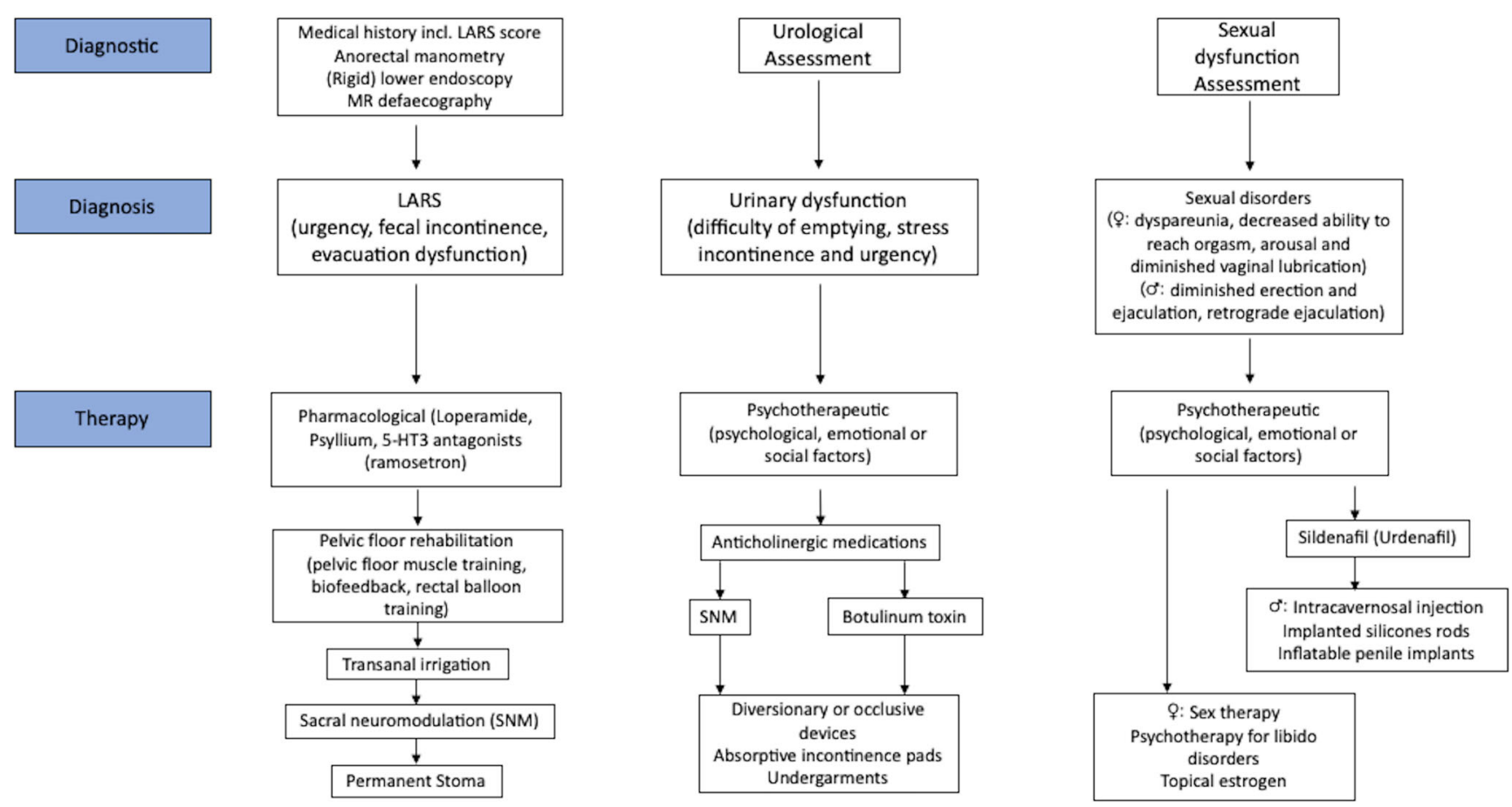

Fig. 2 Diagnostic and therapeutic algorithm for low anterior resection syndrome (LARS) and urogenital dysfunctions after anterior resection (AR) for rectal cancer [SNM: sacral neuromodulation] 
LARS as well as urogenital dysfunction after AR, especially LAR, are frequent. Functional disorders after rectal cancer surgery are largely underestimated among health care professionals. Preoperative screening tools to predict LARS are rarely used and information given to patients is often insufficient [207]. Information dedicated to patients and relatives on websites of colorectal clinics about LARS is lacking important content and material is too complex to understand [208]. Patients experience a lack of supportive care after surgery for functional complaints and do not know who to counsel [209]. With regard to a patient's empowerment surgeons should provide more practical and readily available information on dysfunction after AR and promptly refer patients to their pelvic floor unit for counselling and therapy.

Author's contribution FN, FVA, MVF and DCS participated in the study conception and design, drafting of the article, and critical revision.

Funding Information Open access funding provided by University of Basel. This study is funded by institutional means.

\section{Compliance with ethical standards}

Conflict of interest The authors declare that they have no conflicts of interest.

Ethical approval This article does not contain any studies with human participants or animals performed by any of the authors.

Open Access This article is licensed under a Creative Commons Attribution 4.0 International License, which permits use, sharing, adaptation, distribution and reproduction in any medium or format, as long as you give appropriate credit to the original author(s) and the source, provide a link to the Creative Commons licence, and indicate if changes were made. The images or other third party material in this article are included in the article's Creative Commons licence, unless indicated otherwise in a credit line to the material. If material is not included in the article's Creative Commons licence and your intended use is not permitted by statutory regulation or exceeds the permitted use, you will need to obtain permission directly from the copyright holder. To view a copy of this licence, visit http://creativecommons.org/licenses/by/4.0/.

\section{References}

1. Kapiteijn E, Putter H, van de Velde CJH (2002) Impact of the introduction and training of total mesorectal excision on recurrence and survival in rectal cancer in the Netherlands. Br J Surg 89:1142-1149. https://doi.org/10.1046/j.1365-2168.2002.02196.x

2. Ceelen WP, Van Nieuwenhove Y, Fierens K (2009) Preoperative chemoradiation versus radiation alone for stage II and III resectable rectal cancer. Cochrane Database Syst Rev:CD006041. https://doi.org/10.1002/14651858.CD006041.pub2

3. Sauer R, Becker H, Hohenberger W, Rödel C, Wittekind C, Fietkau R, Martus P, Tschmelitsch J, Hager E, Hess CF, Karstens JH, Liersch T, Schmidberger H, Raab R, German Rectal Cancer Study Group (2004) Preoperative versus postoperative chemoradiotherapy for rectal cancer. N Engl J Med 351: 1731-1740. https://doi.org/10.1056/NEJMoa040694
4. Brown G, Radcliffe AG, Newcombe RG, Dallimore NS, Bourne MW, Williams GT (2003) Preoperative assessment of prognostic factors in rectal cancer using high-resolution magnetic resonance imaging. Br J Surg 90:355-364. https://doi.org/10.1002/bjs.4034

5. Nagtegaal ID, van de Velde CJH, van der Worp E, Kapiteijn E, Quirke P, van Krieken JHJM, the Pathology Review Committee for the Cooperative Clinical Investigators of the Dutch Colorectal Cancer Group (2002) Macroscopic evaluation of rectal cancer resection specimen: clinical significance of the pathologist in quality control. J Clin Oncol Off J Am Soc Clin Oncol 20:1729-1734. https://doi.org/10.1200/JCO.2002.07.010

6. Zeng W-G, Liu M-J, Zhou Z-X, Wang Z-J (2017) A distal resection margin of $\leq 1 \mathrm{~mm}$ and rectal cancer recurrence after sphincterpreserving surgery: the role of a positive distal margin in rectal cancer surgery. Dis Colon Rectum 60:1175-1183. https://doi.org/ 10.1097/DCR.0000000000000900

7. Keranmu A, Liu H-N, Wu Y-C, Liu TT, Li C, Guo TA, Liu FQ, Zheng HT, Xu Y (2018) A negative-doughnut distal resection margin less than $5 \mathrm{~mm}$ does not affect prognosis in rectal cancer. J Surg Oncol 118:536-543. https://doi.org/10.1002/jso.25161

8. Manegold P, Taukert J, Neeff H, Fichtner-Feigl S, Thomusch O (2019) The minimum distal resection margin in rectal cancer surgery and its impact on local recurrence - a retrospective cohort analysis. Int J Surg 69:77-83. https://doi.org/10.1016/j.ijsu.2019.07.029

9. Fleshman J, Branda ME, Sargent DJ, Boller AM, George VV, Abbas MA, Peters WR Jr, Maun DC, Chang GJ, Herline A, Fichera A, Mutch MG, Wexner SD, Whiteford MH, Marks J, Birnbaum E, Margolin DA, Larson DW, Marcello PW, Posner MC, Read TE, Monson JRT, Wren SM, Pisters PWT, Nelson H (2019) Diseasefree survival and local recurrence for laparoscopic resection compared with open resection of stage II to III rectal cancer: follow-up results of the ACOSOG Z6051 randomized controlled trial. Ann Surg 269: 589-595. https://doi.org/10.1097/SLA.0000000000003002

10. Stevenson ARL, Solomon MJ, Brown CSB, Lumley JW, Hewett P, Clouston AD, Gebski VJ, Wilson K, Hague W, Simes J, Australasian Gastro-Intestinal Trials Group (AGITG) ALaCaRT investigators (2019) Disease-free survival and local recurrence after laparoscopic-assisted resection or open resection for rectal cancer: the Australasian laparoscopic cancer of the rectum randomized clinical trial. Ann Surg 269:596-602. https://doi.org/10. 1097/SLA.0000000000003021

11. Bonjer HJ, Deijen CL, Abis GA, Cuesta MA, van der Pas M, de Lange-de Klerk ES, Lacy AM, Bemelman WA, Andersson J, Angenete E, Rosenberg J, Fuerst A, Haglind E, COLOR II Study Group (2015) A randomized trial of laparoscopic versus open surgery for rectal cancer. N Engl J Med 372:1324-1332. https://doi.org/10.1056/NEJMoa1414882

12. Jeong SY, Park JW, Nam BH, Kim S, Kang SB, Lim SB, Choi HS, Kim DW, Chang HJ, Kim DY, Jung KH, Kim TY, Kang GH, Chie EK, Kim SY, Sohn DK, Kim DH, Kim JS, Lee HS, Kim JH, Oh JH (2014) Open versus laparoscopic surgery for mid-rectal or low-rectal cancer after neoadjuvant chemoradiotherapy (COREAN trial): survival outcomes of an open-label, non-inferiority, randomised controlled trial. Lancet Oncol. 15:767-774. https://doi.org/10.1016/S1470-2045(14)70205-0

13. Guillou PJ, Quirke P, Thorpe H et al (2005) Short-term endpoints of conventional versus laparoscopic-assisted surgery in patients with colorectal cancer (MRC CLASICC trial): multicentre, randomised controlled trial. Lancet (London, England) 365: 1718-1726. https://doi.org/10.1016/S0140-6736(05)66545-2

14. Veldkamp R, Kuhry E, Hop WCJ et al (2005) Laparoscopic surgery versus open surgery for colon cancer: short-term outcomes of a randomised trial. Lancet Oncol

15. Jayne DG, Guillou PJ, Thorpe H, Quirke P, Copeland J, Smith AMH, Heath RM, Brown JM (2007) Randomized trial of laparoscopic-assisted resection of colorectal carcinoma: 3-year 
results of the UK MRC CLASICC Trial Group. J Clin Oncol Off J Am Soc Clin Oncol 25:3061-3068. https://doi.org/10.1200/JCO. 2006.09.7758

16. Buunen M, Veldkamp R, Hop WCJ et al (2009) Survival after laparoscopic surgery versus open surgery for colon cancer: longterm outcome of a randomised clinical trial. Lancet Oncol 10:44 52. https://doi.org/10.1016/S1470-2045(08)70310-3

17. Bryant CLC, Lunniss PJ, Knowles CH, Thaha MA, Chan CLH (2012) Anterior resection syndrome. Lancet Oncol 13:e403-e408

18. Brookes SJ, Dinning PG, Gladman MA (2009) Neuroanatomy and physiology of colorectal function and defaecation: from basic science to human clinical studies. Neurogastroenterol Motil Off J Eur Gastrointest Motil Soc 21(Suppl 2):9-19. https://doi.org/10. 1111/j.1365-2982.2009.01400.x

19. Koda K, Yamazaki M, Shuto K, Kosugi C, Mori M, Narushima K, Hosokawa I, Shimizu H (2019) Etiology and management of low anterior resection syndrome based on the normal defecation mechanism. Surg Today 49:803-808. https://doi.org/10.1007/s00595019-01795-9

20. Bassotti G, de Roberto G, Castellani D, Sediari L, Morelli A (2005) Normal aspects of colorectal motility and abnormalities in slow transit constipation. World J Gastroenterol 11:26912696. https://doi.org/10.3748/wjg.v11.i18.2691

21. Lin AY, Dinning PG, Milne T, Bissett IP, O'Grady G (2017) The "rectosigmoid brake": review of an emerging neuromodulation target for colorectal functional disorders. Clin Exp Pharmacol Physiol 44:719-728. https://doi.org/10.1111/1440-1681.12760

22. Battersby NJ, Juul T, Christensen P, Janjua AZ, Branagan G, Emmertsen KJ, Norton C, Hughes R, Laurberg S, Moran BJ, United Kingdom Low Anterior Resection Syndrome Study Group (2016) Predicting the risk of bowel-related quality-of-life impairment after restorative resection for rectal cancer: a multicenter cross-sectional study. Dis Colon Rectum 59:270-280. https:// doi.org/10.1097/DCR.0000000000000552

23. Emmertsen KJ, Laurberg S (2013) Impact of bowel dysfunction on quality of life after sphincter-preserving resection for rectal cancer. Br J Surg 100:1377-1387. https://doi.org/10.1002/bjs.9223

24. Ihnát P, Slívová I, Tulinsky L, Ihnát Rudinská L, Máca J, Penka I (2018) Anorectal dysfunction after laparoscopic low anterior rectal resection for rectal cancer with and without radiotherapy (manometry study). J Surg Oncol 117:710-716. https://doi.org/10. $1002 /$ jso. 24885

25. Krol R, McColl GM, Hopman WPM, Smeenk RJ (2018) Anal and rectal function after intensity-modulated prostate radiotherapy with endorectal balloon. Radiother Oncol J Eur Soc Ther Radiol Oncol 128:364-368. https://doi.org/10.1016/j.radonc.2018.03.032

26. Ziv Y, Zbar A, Bar-Shavit Y, Igov I (2013) Low anterior resection syndrome (LARS): cause and effect and reconstructive considerations. Tech Coloproctol 17:151-162. https://doi.org/10.1007/ s10151-012-0909-3

27. Ziv Y, Gimelfarb Y, Igov I (2013) Post anterior rectal resection syndrome-a retrospective multicentre study. Color Dis Off $\mathrm{J}$ Assoc Coloproctology Gt Britain Irel 15:e317-e322. https://doi. org/10.1111/codi.12176

28. Koda K, Saito N, Seike K, Shimizu K, Kosugi C, Miyazaki M (2005) Denervation of the neorectum as a potential cause of defecatory disorder following low anterior resection for rectal cancer. Dis Colon Rectum 48:210-217. https://doi.org/10.1007/ s10350-004-0814-6

29. Shimizu K, Koda K, Kase Y, Satoh K, Seike K, Nishimura M, Kosugi C, Miyazaki M (2006) Induction and recovery of colonic motility/defecatory disorders after extrinsic denervation of the colon and rectum in rats. Surgery 139:395-406. https://doi.org/10. 1016/j.surg.2005.08.018

30. Emmertsen KJ, Bregendahl S, Fassov J, Krogh K, Laurberg S (2013) A hyperactive postprandial response in the neorectum- the clue to low anterior resection syndrome after total mesorectal excision surgery? Color Dis Off J Assoc Coloproctology Gt Britain Irel 15:e599-e606. https://doi.org/10.1111/codi.12360

31. Machado M, Nygren J, Goldman S, Ljungqvist O (2003) Similar outcome after colonic pouch and side-to-end anastomosis in low anterior resection for rectal cancer: a prospective randomized trial. Ann Surg 238:214-220. https://doi.org/10.1097/01.sla. 0000080824.10891.e1

32. Kakodkar R, Gupta S, Nundy S (2006) Low anterior resection with total mesorectal excision for rectal cancer: functional assessment and factors affecting outcome. Color Dis Off $\mathrm{J}$ Assoc Coloproctology Gt Britain Irel 8:650-656. https://doi.org/10. 1111/j.1463-1318.2006.00992.x

33. Desnoo L, Faithfull S (2006) A qualitative study of anterior resection syndrome: the experiences of cancer survivors who have undergone resection surgery. Eur J Cancer Care (Engl) 15:244-251. https://doi.org/10.1111/j.1365-2354.2005.00647.x

34. Lee WY, Takahashi T, Pappas T, Mantyh CR, Ludwig KA (2008) Surgical autonomic denervation results in altered colonic motility: an explanation for low anterior resection syndrome? Surgery 143: 778-783. https://doi.org/10.1016/j.surg.2008.03.014

35. Farouk R, Duthie GS, Lee PW, Monson JR (1998) Endosonographic evidence of injury to the internal anal sphincter after low anterior resection: long-term follow-up. Dis Colon Rectum 41:888-891. https://doi.org/10.1007/BF02235373

36. Ho YH, Tsang C, Tang CL, Nyam D, Eu KW, Seow-Choen F (2000) Anal sphincter injuries from stapling instruments introduced transanally: randomized, controlled study with endoanal ultrasound and anorectal manometry. Dis Colon Rectum 43: 169-173. https://doi.org/10.1007/BF02236976

37. Winter DC, Murphy A, Kell MR, Shields CJ, Redmond HP, Kirwan WO (2004) Perioperative topical nitrate and sphincter function in patients undergoing transanal stapled anastomosis: a randomized, placebo-controlled, double-blinded trial. Dis Colon Rectum 47:697-703. https://doi.org/10.1007/s10350-003-0120-8

38. Matsuoka H, Masaki T, Kobayashi T, Sato K, Mori T, Sugiyama M, Atomi Y (2010) Neurophysiologic investigation of anal function following double stapling anastomosis. Dig Surg 27:320323. https://doi.org/10.1159/000281814

39. Ishiyama G, Hinata N, Kinugasa Y, Murakami G, Fujimiya M (2014) Nerves supplying the internal anal sphincter: an immunohistochemical study using donated elderly cadavers. Surg Radiol Anat 36:1033-1042. https://doi.org/10.1007/s00276-014-1289-3

40. Koda K, Yasuda H, Hirano A, Kosugi C, Suzuki M, Yamazaki M, Tezuka T, Higuchi R, Tsuchiya H, Saito N (2009) Evaluation of postoperative damage to anal sphincter/levator ani muscles with three-dimensional vector manometry after sphincter-preserving operation for rectal cancer. J Am Coll Surg 208:362-367. https://doi.org/10.1016/j.jamcollsurg.2008.10.035

41. Courtney H (1950) Anatomy of the pelvic diaphragm and anorectal musculature as related to sphincter preservation in anorectal surgery. Am J Surg 79:155-173, illust. https://doi.org/ 10.1016/0002-9610(50)90208-x

42. Muro S, Yamaguchi K, Nakajima Y, Watanabe K, Harada M, Nimura A, Akita K (2014) Dynamic intersection of the longitudinal muscle and external anal sphincter in the layered structure of the anal canal posterior wall. Surg Radiol Anat 36:551-559. https://doi.org/10.1007/s00276-013-1228-8

43. Croese AD, Zubair ON, Lonie J, Trollope AF, Vangaveti VN, Mushaya C, Ho YH (2018) Prevalence of low anterior resection syndrome at a regional Australian centre. ANZ J Surg 88:E813E817. https://doi.org/10.1111/ans.14749

44. Hughes DL, Cornish J, Morris C (2017) Functional outcome following rectal surgery-predisposing factors for low anterior resection syndrome. Int J Color Dis 32:691-697. https://doi.org/10. 1007/s00384-017-2765-0 
45. Sun W, Dou R, Chen J, Lai S, Zhang C, Ruan L, Kang L, Deng Y, Lan P, Wang L, Wang J (2019) Impact of long-course neoadjuvant radiation on postoperative low anterior resection syndrome and quality of life in rectal cancer: post hoc analysis of a randomized controlled trial. Ann Surg Oncol 26:746-755. https://doi.org/ 10.1245/s10434-018-07096-8

46. Gadan S, Floodeen H, Lindgren R, Matthiessen P (2017) Does a defunctioning stoma impair anorectal function after low anterior resection of the rectum for cancer? A 12-year follow-up of a randomized multicenter trial. Dis Colon Rectum 60:800-806. https:// doi.org/10.1097/DCR.0000000000000818

47. Juul T, Ahlberg M, Biondo S, Espin E, Jimenez LM, Matzel KE, Palmer GJ, Sauermann A, Trenti L, Zhang W, Laurberg S, Christensen P (2014) Low anterior resection syndrome and quality of life: an international multicenter study. Dis Colon Rectum 57: 585-591. https://doi.org/10.1097/DCR.0000000000000116

48. Sakr A, Yang SY, Kang JH, Cho MS, Han YD, Min BS, Thabet W, Elbanna HG, Morshed M, Kim NK (2019) Oncologic safety and bowel function after ultralow anterior resection with or without intersphincteric resection for low lying rectal cancer: comparative cross sectional study. J Surg Oncol 121:365-374. https://doi. org/10.1002/jso.25791

49. Pedersen IK, Christiansen J, Hint K et al (1986) Anorectal function after low anterior resection for carcinoma. Ann Surg 204: 133-135. https://doi.org/10.1097/00000658-198608000-00006

50. van Duijvendijk P, Slors JFM, Taat CW et al (2002) Prospective evaluation of anorectal function after total mesorectal excision for rectal carcinoma with or without preoperative radiotherapy. Am J Gastroenterol 97:2282-2289. https://doi.org/10.1111/j.15720241.2002.05782.x

51. Oya M, Komatsu J, Takase Y, Nakamura T, Ishikawa H (2002) Comparison of defecatory function after colonic J-pouch anastomosis and straight anastomosis for stapled low anterior resection: results of a prospective randomized trial. Surg Today 32:104-110. https://doi.org/10.1007/s005950200001

52. Croese AD, Lonie JM, Trollope AF, Vangaveti VN, Ho YH (2018) A meta-analysis of the prevalence of low anterior resection syndrome and systematic review of risk factors. Int J Surg 56: 234-241. https://doi.org/10.1016/j.jisu.2018.06.031

53. Emmertsen KJ, Laurberg S (2012) Low anterior resection syndrome score: development and validation of a symptom-based scoring system for bowel dysfunction after low anterior resection for rectal cancer. Ann Surg 255:922-928. https://doi.org/10.1097/ SLA.0b013e31824f1c21

54. Juul T, Elfeki H, Christensen P, Laurberg S, Emmertsen KJ, Bager P (2019) Normative data for the low anterior resection syndrome score (LARS score). Ann Surg 269:1124-1128. https://doi.org/10. 1097/SLA.0000000000002750

55. van Heinsbergen M, Van der Heijden JAG, Stassen LP et al (2020) The low anterior resection syndrome in a reference population: prevalence and predictive factors in the Netherlands. Color Dis Off J Assoc Coloproctology Gt Britain Irel 22:46-52. https:// doi.org/10.1111/codi.14790

56. Buchli C, Martling A, Sjövall A (2019) Low anterior resection syndrome after right- and left-sided resections for colonic cancer. BJS open 3:387-394. https://doi.org/10.1002/bjs5.50128

57. Bregendahl S, Emmertsen KJ, Lous J, Laurberg S (2013) Bowel dysfunction after low anterior resection with and without neoadjuvant therapy for rectal cancer: a population-based cross-sectional study. Color Dis Off J Assoc Coloproctology Gt Britain Irel 15: 1130-1139. https://doi.org/10.1111/codi.12244

58. Rockwood TH, Church JM, Fleshman JW, Kane RL, Mavrantonis C, Thorson AG, Wexner SD, Bliss D, Lowry AC (1999) Patient and surgeon ranking of the severity of symptoms associated with fecal incontinence: the fecal incontinence severity index. Dis
Colon Rectum 42:1525-1531. https://doi.org/10.1007/ BF02236199

59. Vaizey CJ, Carapeti E, Cahill JA, Kamm MA (1999) Prospective comparison of faecal incontinence grading systems. Gut. 44:7780. https://doi.org/10.1136/gut.44.1.77

60. Temple LK, Bacik J, Savatta SG, Gottesman L, Paty PB, Weiser MR, Guillem JG, Minsky BD, Kalman M, Thaler HT, Schrag D, Wong DW (2005) The development of a validated instrument to evaluate bowel function after sphincter-preserving surgery for rectal cancer. Dis. Colon Rectum 48:1353-1365

61. Jorge JMN, Wexner SD (1993) Etiology and management of fecal incontinence. Dis Colon Rectum 36:77-97. https://doi.org/10. 1007/BF02050307

62. Borstlap WAA, van Oostendorp SE, Klaver CEL, Hahnloser D, Cunningham C, Rullier E, Bemelman WA, Tuynman JB, Tanis PJ, the Research Committee of the European Society of Coloproctology (2018) Organ preservation in rectal cancer: a synopsis of current guidelines. Color Dis 20:201-210. https://doi.org/ 10.1111/codi.13960

63. Sauer R, Liersch T, Merkel S, Fietkau R, Hohenberger W, Hess C, Becker H, Raab HR, Villanueva MT, Witzigmann H, Wittekind C, Beissbarth T, Rödel C (2012) Preoperative versus postoperative chemoradiotherapy for locally advanced rectal cancer: results of the German CAO/ARO/AIO-94 randomized phase III trial after a median follow-up of 11 years. J Clin Oncol Off J Am Soc Clin Oncol 30:1926-1933. https://doi.org/10.1200/JCO.2011.40.1836

64. Kapiteijn E, Marijnen CA, Nagtegaal ID, Putter H, Steup WH, Wiggers T, Rutten HJ, Pahlman L, Glimelius B, van Krieken J, Leer JW, van de Velde C, Dutch Colorectal Cancer Group (2001) Preoperative radiotherapy combined with total mesorectal excision for resectable rectal cancer. N Engl J Med 345:638-646. https://doi.org/10.1056/NEJMoa010580

65. Maas M, Nelemans PJ, Valentini V, Das P, Rödel C, Kuo LJ, Calvo FA, García-Aguilar J, Glynne-Jones R, Haustermans K, Mohiuddin M, Pucciarelli S, Small W Jr, Suárez J, Theodoropoulos G, Biondo S, Beets-Tan RGH, Beets GL (2010) Long-term outcome in patients with a pathological complete response after chemoradiation for rectal cancer: a pooled analysis of individual patient data. Lancet Oncol 11:835-844. https://doi.org/10.1016/S1470-2045(10)70172-8

66. Haak HE, Maas M, Lambregts DMJ et al (2020) Is watch and wait a safe and effective way to treat rectal cancer in older patients? Eur J Surg Oncol J Eur Soc Surg Oncol Br Assoc Surg Oncol 46:358 362. https://doi.org/10.1016/j.ejso.2020.01.005

67. Hupkens BJP, Martens MH, Stoot JH, Berbee M, Melenhorst J, Beets-Tan RG, Beets GL, Breukink SO (2017) Quality of life in rectal cancer patients after chemoradiation: watch-and-wait policy versus standard resection - a matched-controlled study. Dis Colon Rectum 60:1032-1040. https://doi.org/10.1097/DCR.0000000000000862

68. Dossa F, Chesney TR, Acuna SA, Baxter NN (2017) A watch-andwait approach for locally advanced rectal cancer after a clinical complete response following neoadjuvant chemoradiation: a systematic review and meta-analysis. Lancet Gastroenterol Hepatol 2:501-513. https://doi.org/10.1016/S2468-1253(17)30074-2

69. Capelli G, De Simone I, Spolverato G et al (2020) Non-operative management versus total mesorectal excision for locally advanced rectal cancer with clinical complete response after neoadjuvant chemoradiotherapy: a GRADE approach by the Rectal Cancer Guidelines Writing Group of the Italian Association of Medical Oncology (AIOM). J Gastrointest Surg Off J Soc Surg Aliment Tract. https://doi.org/10.1007/s11605-020-04635-1

70. Lu J-Y, Lin G-L, Qiu H-Z, Xiao Y, Wu B, Zhou JL (2015) Comparison of transanal endoscopic microsurgery and total mesorectal excision in the treatment of $\mathrm{T} 1$ rectal cancer: a metaanalysis. PLoS One 10:e0141427. https://doi.org/10.1371/journal. pone. 0141427 
71. Stijns RCH, de Graaf EJR, Punt CJA, Nagtegaal ID, Nuyttens JJME, van Meerten E, Tanis PJ, de Hingh IHJT, van der Schelling GP, Acherman Y, Leijtens JWA, Bremers AJA, Beets GL, Hoff C, Verhoef C, Marijnen CAM, de Wilt JHW, for the CARTS Study Group (2019) Long-term oncological and functional outcomes of chemoradiotherapy followed by organ-sparing transanal endoscopic microsurgery for distal rectal cancer: the CARTS study. JAMA Surg 154:47-54. https://doi.org/10.1001/jamasurg.2018.3752

72. Rullier E, Rouanet P, Tuech J-J et al (2017) Organ preservation for rectal cancer (GRECCAR 2): a prospective, randomised, openlabel, multicentre, phase 3 trial. Lancet (London, England) 390: 469-479. https://doi.org/10.1016/S0140-6736(17)31056-5

73. Franca Neto PR, de Queiroz FL, Staino IRFL, Lacerda Filho A (2013) Quality of life assessment in the late postoperative period of patients with rectal cancer submitted to total mesorectal excision. J Coloproctology (Rio Janeiro) 33:50-57. https://doi.org/10. 1590/s2237-93632013000200002

74. Contin P, Kulu Y, Bruckner T, Sturm M, Welsch T, Müller-Stich BP, Huber J, Büchler MW, Ulrich A (2014) Comparative analysis of late functional outcome following preoperative radiation therapy or chemoradiotherapy and surgery or surgery alone in rectal cancer. Int J Color Dis 29:165-175. https://doi.org/10.1007/ s00384-013-1780-z

75. Stephens RJ, Thompson LC, Quirke P, Steele R, Grieve R, Couture J, Griffiths GO, Sebag-Montefiore D (2010) Impact of short-course preoperative radiotherapy for rectal cancer on patients' quality of life: data from the Medical Research Council CR07/National Cancer Institute of Canada Clinical Trials Group C016 randomized clinical trial. J Clin Oncol 28:4233-4239. https://doi.org/10.1200/JCO.2009.26.5264

76. Lange MM, Den Dulk M, Bossema ER et al (2007) Risk factors for faecal incontinence after rectal cancer treatment. Br J Surg 94: 1278-1284. https://doi.org/10.1002/bjs.5819

77. Downing A, Glaser AW, Finan PJ, Wright P, Thomas JD, Gilbert A, Corner J, Richards M, Morris EJA, Sebag-Montefiore D (2019) Functional outcomes and health-related quality of life after curative treatment for rectal cancer: a population-level study in England. Int J Radiat Oncol Biol Phys 103:1132-1142. https:// doi.org/10.1016/j.ijrobp.2018.12.005

78. Pollack J, Holm T, Cedermark B, Altman D, Holmström B, Glimelius B, Mellgren A (2006) Late adverse effects of shortcourse preoperative radiotherapy in rectal cancer. Br J Surg 93: 1519-1525. https://doi.org/10.1002/bjs.5525

79. Wiltink LM, Marijnen CAM, Meershoek-Klein Kranenbarg E, van de Velde CJH, Nout RA (2016) A comprehensive longitudinal overview of health-related quality of life and symptoms after treatment for rectal cancer in the TME trial. Acta Oncol 55:502508. https://doi.org/10.3109/0284186X.2015.1088171

80. Merkel S, Weber K, Schellerer V, Göhl J, Fietkau R, Agaimy A, Hohenberger W, Hermanek P (2014) Prognostic subdivision of ypT3 rectal tumours according to extension beyond the muscularis propria. Br J Surg 101:566-572. https://doi.org/10.1002/bjs.9419

81. Taylor FGM, Quirke P, Heald RJ, Moran B, Blomqvist L, Swift I, Sebag-Montefiore DJ, Tekkis P, Brown G, MERCURY study group (2011) Preoperative high-resolution magnetic resonance imaging can identify good prognosis stage I, II, and III rectal cancer best managed by surgery alone: a prospective, multicenter, European study. Ann Surg 253:711-719. https://doi.org/10.1097/ SLA.0b013e31820b8d52

82. Cornish JA, Tilney HS, Heriot AG, Lavery IC, Fazio VW, Tekkis PP (2007) A meta-analysis of quality of life for abdominoperineal excision of rectum versus anterior resection for rectal cancer. Ann Surg Oncol 14:2056-2068. https://doi.org/10.1245/s10434-007-9402-Z

83. Battersby NJ, Bouliotis G, Emmertsen KJ, Juul T, Glynne-Jones R, Branagan G, Christensen P, Laurberg S, Moran BJ (2018) Development and external validation of a nomogram and online tool to predict bowel dysfunction following restorative rectal cancer resection: the POLARS score. Gut 67:688-696. https://doi. org/10.1136/gutjnl-2016-312695

84. Zolciak A, Bujko K, Kepka L, Oledzki J, Rutkowski A, Nowacki MP (2006) Abdominoperineal resection or anterior resection for rectal cancer: patient preferences before and after treatment. Color Dis Off J Assoc Coloproctology Gt Britain Irel 8:575-580. https:// doi.org/10.1111/j.1463-1318.2006.01000.x

85. Pucciani F (2013) A review on functional results of sphincter-saving surgery for rectal cancer: the anterior resection syndrome. Updat Surg 65:257-263. https://doi.org/10.1007/s13304-013-0220-5

86. Seow-Choen F, Goh HS (1995) Prospective randomized trial comparing J colonic pouch-anal anastomosis and straight coloanal reconstruction. Br J Surg 82:608-610. https://doi.org/10.1002/bjs. 1800820511

87. Heriot AG, Tekkis PP, Constantinides V, Paraskevas P, Nicholls RJ, Darzi A, Fazio VW (2006) Meta-analysis of colonic reservoirs versus straight coloanal anastomosis after anterior resection. Br J Surg 93:19-32. https://doi.org/10.1002/bjs.5188

88. Ulrich AB, Seiler CM, Z'graggen K et al (2008) Early results from a randomized clinical trial of colon $J$ pouch versus transverse coloplasty pouch after low anterior resection for rectal cancer. $\mathrm{Br}$ J Surg 95:1257-1263. https://doi.org/10.1002/bjs.6301

89. Ho Y-H, Brown S, Heah S-M, Tsang C, Seow-Choen F, Eu KW, Tang CL (2002) Comparison of J-pouch and coloplasty pouch for low rectal cancers: a randomized, controlled trial investigating functional results and comparative anastomotic leak rates. Ann Surg 236: 49-55. https://doi.org/10.1097/00000658-200207000-00009

90. Fazio VW, Zutshi M, Remzi FH, Parc Y, Ruppert R, Fürst A, Celebrezze J Jr, Galanduik S, Orangio G, Hyman N, Bokey L, Tiret E, Kirchdorfer B, Medich D, Tietze M, Hull T, Hammel J (2007) A randomized multicenter trial to compare long-term functional outcome, quality of life, and complications of surgical procedures for low rectal cancers. Ann Surg 246:481-490. https://doi. org/10.1097/SLA.0b013e3181485617

91. Jiang J-K, Yang S-H, Lin J-K (2005) Transabdominal anastomosis after low anterior resection: a prospective, randomized, controlled trial comparing long-term results between side-to-end anastomosis and colonic J-pouch. Dis Colon Rectum 48:2100-2110. https://doi.org/10.1007/s10350-005-0139-0

92. Tsunoda A, Kamiyama G, Narita K, Watanabe M, Nakao K, Kusano M (2009) Prospective randomized trial for determination of optimum size of side limb in low anterior resection with side-toend anastomosis for rectal carcinoma. Dis Colon Rectum 52: 1572-1577. https://doi.org/10.1007/DCR.0b013e3181a909d4

93. Machado M, Nygren J, Goldman S, Ljungqvist O (2005) Functional and physiologic assessment of the colonic reservoir or side-to-end anastomosis after low anterior resection for rectal cancer: a two-year follow-up. Dis Colon Rectum 48:29-36. https://doi.org/10.1007/s10350-004-0772-z

94. Brown CJ, Fenech D, McLeod RS (2008) Reconstructive techniques after rectal resection for rectal cancer. Cochrane Database Syst Rev. https://doi.org/10.1002/14651858.CD006040.pub2

95. Hüttner FJ, Tenckhoff S, Jensen K, Uhlmann L, Kulu Y, Büchler MW, Diener MK, Ulrich A (2015) Meta-analysis of reconstruction techniques after low anterior resection for rectal cancer. Br J Surg 102:735-745. https://doi.org/10.1002/bjs.9782

96. Parc Y, Ruppert R, Fuerst A, Golcher H, Zutshi M, Hull T, Tiret E, Hemminger F, Galandiuk S, Fender S, Weber K, Zimmerman A, Aiello A, Fazio V (2019) Better function with a colonic J-pouch or a side-to-end anastomosis?: a randomized controlled trial to compare the complications, functional outcome, and quality of life in patients with low rectal cancer after a J-pouch or a side-to-end anastomosis. Ann Surg 269:815-826. https://doi.org/10.1097/ SLA.0000000000003249 
97. Marti WR, Curti G, Wehrli H, Grieder F, Graf M, Gloor B, Zuber M, Demartines N, Fasolini F, Lerf B, Kettelhack C, Andrieu C, Bigler M, Hayoz S, Ribi K, Hamel C, Swiss Group for Clinical Cancer Research (SAKK), Section Surgery (2019) Clinical outcome after rectal replacement with side-to-end, colon-J-pouch, or straight colorectal anastomosis following total mesorectal excision: a Swiss prospective, randomized, multicenter trial (SAKK 40/04). Ann Surg 269:827-835. https://doi.org/10.1097/SLA. 0000000000003057

98. Cheong C, Oh SY, Choi SJ, Suh KW (2019) Ultralow anterior resection and coloanal anastomosis for low-lying rectal cancer: an appraisal based on bowel function. Dig Surg 36:409-417. https:// doi.org/10.1159/000490899

99. Lovegrove RE, Constantinides VA, Heriot AG, Athanasiou T, Darzi A, Remzi FH, Nicholls RJ, Fazio VW, Tekkis PP (2006) A comparison of hand-sewn versus stapled ileal pouch anal anastomosis (IPAA) following proctocolectomy: a meta-analysis of 4183 patients. Ann Surg 244:18-26. https://doi.org/10.1097/01. sla.0000225031.15405.a3

100. Matthiessen P, Hallböök O, Rutegård J et al (2007) Defunctioning stoma reduces symptomatic anastomotic leakage after low anterior resection of the rectum for cancer: a randomized multicenter trial. Ann Surg 246:207-214. https://doi.org/10.1097/SLA. 0b013e3180603024

101. Jiménez-Rodríguez RM, Segura-Sampedro JJ, Rivero-Belenchón I, Díaz Pavón JM, García Cabrera AM, Vazquez Monchul JM, Padillo J, de la Portilla F (2017) Is the interval from surgery to ileostomy closure a risk factor for low anterior resection syndrome? Color Dis Off J Assoc Coloproctology Gt Britain Irel 19:485-490. https://doi.org/10.1111/codi.13524

102. Keane C, Park J, Öberg S, Wedin A, Bock D, O'Grady G, Bissett I, Rosenberg J, Angenete E (2019) Functional outcomes from a randomized trial of early closure of temporary ileostomy after rectal excision for cancer. Br J Surg 106:645-652. https://doi. org/10.1002/bjs. 11092

103. Kang SB, Park JW, Jeong SY, Nam BH, Choi HS, Kim DW, Lim SB, Lee TG, Kim DY, Kim JS, Chang HJ, Lee HS, Kim SY, Jung KH, Hong YS, Kim JH, Sohn DK, Kim DH, Oh JH (2010) Open versus laparoscopic surgery for mid or low rectal cancer after neoadjuvant chemoradiotherapy (COREAN trial): short-term outcomes of an open-label randomised controlled trial. Lancet Oncol 11:637-645. https://doi.org/10.1016/S1470-2045(10)70131-5

104. Andersson J, Angenete E, Gellerstedt M, Angerås U, Jess P, Rosenberg J, Fürst A, Bonjer J, Haglind E (2013) Health-related quality of life after laparoscopic and open surgery for rectal cancer in a randomized trial. Br J Surg 100:941-949. https://doi.org/10. 1002/bjs. 9144

105. Perdawood SK, Al Khefagie GAA (2016) Transanal vs laparoscopic total mesorectal excision for rectal cancer: initial experience from Denmark. Color Dis Off J Assoc Coloproctology Gt Britain Irel 18:51-58. https://doi.org/10.1111/codi.13225

106. Perdawood SK, Thinggaard BS, Bjoern MX (2018) Effect of transanal total mesorectal excision for rectal cancer: comparison of short-term outcomes with laparoscopic and open surgeries. Surg Endosc 32:2312-2321. https://doi.org/10.1007/s00464017-5926-x

107. Rasulov AO, Mamedli ZZ, Gordeyev SS, Kozlov NA, Dzhumabaev HE (2016) Short-term outcomes after transanal and laparoscopic total mesorectal excision for rectal cancer. Tech Coloproctol 20:227-234. https://doi.org/10.1007/s10151015-1421-3

108. Xu W, Xu Z, Cheng H, Ying J, Cheng F, Xu W, Cao J, Luo J (2016) Comparison of short-term clinical outcomes between transanal and laparoscopic total mesorectal excision for the treatment of mid and low rectal cancer: a meta-analysis. Eur J Surg
Oncol J Eur Soc Surg Oncol Br Assoc Surg Oncol 42:1841-1850. https://doi.org/10.1016/j.ejso.2016.09.002

109. Rubinkiewicz M, Zarzycki P, Witowski J, Pisarska M, Gajewska N, Torbicz G, Nowakowski M, Major P, Budzyński A, Pędziwiatr M (2019) Functional outcomes after resections for low rectal tumors: comparison of transanal with laparoscopic total mesorectal excision. BMC Surg 19:79. https://doi.org/10.1186/s12893-0190550-4

110. Veltcamp Helbach M, Koedam TWA, Knol JJ, Velthuis S, Bonjer HJ, Tuynman JB, Sietses C (2019) Quality of life after rectal cancer surgery: differences between laparoscopic and transanal total mesorectal excision. Surg Endosc 33:79-87. https://doi.org/ 10.1007/s00464-018-6276-Z

111. Dou R, Sun W, Luo S, Hou Y, Zhang C, Kang L (2019) Comparison of postoperative bowel function between patients undergoing transanal and laparoscopic total mesorectal excision. Zhonghua Wei Chang Wai Ke Za Zhi 22:246-254

112. van der Heijden JAG, Koëter T, Smits LJH et al (2020) Functional complaints and quality of life after transanal total mesorectal excision: a meta-analysis. Br J Surg

113. Bjoern MX, Nielsen S, Perdawood SK (2019) Quality of life after surgery for rectal cancer: a comparison of functional outcomes after transanal and laparoscopic approaches. J Gastrointest Surg Off J Soc Surg Aliment Tract 23:1623-1630. https://doi.org/10. 1007/s11605-018-4057-6

114. Kim JY, Kim NK, Lee KY, Hur H, Min BS, Kim JH (2012) A comparative study of voiding and sexual function after total mesorectal excision with autonomic nerve preservation for rectal cancer: laparoscopic versus robotic surgery. Ann Surg Oncol 19: 2485-2493. https://doi.org/10.1245/s10434-012-2262-1

115. D'Annibale A, Pernazza G, Monsellato I, Pende V, Lucandri G, Mazzocchi P, Alfano G (2013) Total mesorectal excision: a comparison of oncological and functional outcomes between robotic and laparoscopic surgery for rectal cancer. Surg Endosc 27:18871895. https://doi.org/10.1007/s00464-012-2731-4

116. Colombo P-E, Bertrand MM, Alline M, Boulay E, Mourregot A, Carrère $S$, Quénet $F$, Jarlier M, Rouanet $P$ (2016) Robotic versus laparoscopic total mesorectal excision (TME) for sphincter-saving surgery: is there any difference in the transanal TME rectal approach?: a single-center series of 120 consecutive patients. Ann Surg Oncol 23:1594-1600. https://doi.org/10.1245/s10434-0155048-4

117. Kim JC, Lee JL, Bong JW, Seo JH, Kim CW, Park SH, Kim J (2020) Oncological and anorectal functional outcomes of robotassisted intersphincteric resection in lower rectal cancer, particularly the extent of sphincter resection and sphincter saving. Surg Endosc 34:2082-2094. https://doi.org/10.1007/s00464-01906989-3

118. Lee SH, Kim DH, Lim SW (2018) Robotic versus laparoscopic intersphincteric resection for low rectal cancer: a systematic review and meta-analysis. Int J Color Dis 33:1741-1753. https:// doi.org/10.1007/s00384-018-3145-0

119. Bolton WS, Chapman SJ, Corrigan N, Croft J, Collinson F, Brown JM, Jayne DG (2020) The incidence of low anterior resection syndrome as assessed in an international randomized controlled trial (MRC/NIHR ROLARR). Ann Surg. https://doi.org/10.1097/ SLA.0000000000003806

120. Kneist W, Kauff DW, Gockel I, Huppert S, Koch KP, Hoffmann KP, Lang H (2012) Total mesorectal excision with intraoperative assessment of internal anal sphincter innervation provides new insights into neurogenic incontinence. J Am Coll Surg 214:306312. https://doi.org/10.1016/j.jamcollsurg.2011.11.013

121. Kneist W, Kauff DW, Juhre V, Hoffmann KP, Lang H (2013) Is intraoperative neuromonitoring associated with better functional outcome in patients undergoing open TME?: results of a case- 
control study. Eur J Surg Oncol 39:994-999. https://doi.org/10. 1016/j.ejso.2013.06.004

122. Kauff DW, Wachter N, Bettzieche R, Lang H, Kneist W (2016) Electrophysiology-based quality assurance of nerve-sparing in laparoscopic rectal cancer surgery: is it worth the effort? Surg Endosc 30:4525-4532. https://doi.org/10.1007/s00464-0164787-z

123. Kauff DW, Roth YDS, Bettzieche RS, Kneist W (2020) Fecal incontinence after total mesorectal excision for rectal cancerimpact of potential risk factors and pelvic intraoperative neuromonitoring. World J Surg Oncol 18:12. https://doi.org/10. 1186/s12957-020-1782-6

124. Zhou M-W, Huang X-Y, Chen Z-Y, Li ZY, Zhou YM, Yang Y, Wang ZH, Xiang JB, Gu XD (2019) Intraoperative monitoring of pelvic autonomic nerves during laparoscopic low anterior resection of rectal cancer. Cancer Manag Res 11:411-417. https://doi. org/10.2147/CMAR.S182181

125. Kauff DW, Kronfeld K, Gorbulev S, Wachtlin D, Lang H, Kneist W (2016) Continuous intraoperative monitoring of pelvic autonomic nerves during TME to prevent urogenital and anorectal dysfunction in rectal cancer patients (NEUROS): a randomized controlled trial. BMC Cancer 16:323. https://doi.org/10.1186/ s12885-016-2348-4

126. Hallgren T, Fasth S, Delbro DS, Nordgren S, Öresland T, Hultén L (1994) Loperamide improves anal sphincter function and continence after restorative proctocolectomy. Dig Dis Sci 39:26122618. https://doi.org/10.1007/BF02087698

127. Markland AD, Burgio KL, Whitehead WE, Richter HE, Wilcox CM, Redden DT, Beasley TM, Goode PS (2015) Loperamide versus psyllium fiber for treatment of fecal incontinence: the fecal incontinence prescription ( $\mathrm{Rx}$ ) management (FIRM) randomized clinical trial. Dis Colon Rectum 58:983-993. https://doi.org/10. 1097/DCR.0000000000000442

128. Itagaki R, Koda K, Yamazaki M et al (2014) Serotonin (5-HT3) receptor antagonists for the reduction of symptoms of low anterior resection syndrome. Clin Exp Gastroenterol 7:47-52. https://doi. org/10.2147/CEG.S55410

129. Spiller RC (2011) Targeting the 5-HT(3) receptor in the treatment of irritable bowel syndrome. Curr Opin Pharmacol 11:68-74. https://doi.org/10.1016/j.coph.2011.02.005

130. Lin HC (2004) Small intestinal bacterial overgrowth: a framework for understanding irritable bowel syndrome. JAMA 292:852-858. https://doi.org/10.1001/jama.292.7.852

131. Stephens JH, Hewett PJ (2012) Clinical trial assessing VSL\#3 for the treatment of anterior resection syndrome. ANZ J Surg 82:420 427. https://doi.org/10.1111/j.1445-2197.2012.06082.x

132. Bols E, Berghmans B, de Bie R, Govaert B, van Wunnik B, Heymans M, Hendriks E, Baeten C (2012) Rectal balloon training as add-on therapy to pelvic floor muscle training in adults with fecal incontinence: a randomized controlled trial. Neurourol Urodyn 31:132-138. https://doi.org/10.1002/nau.21218

133. Visser WS, Te Riele WW, Boerma D et al (2014) Pelvic floor rehabilitation to improve functional outcome after a low anterior resection: a systematic review. Ann Coloproctol 30:109-114. https://doi.org/10.3393/ac.2014.30.3.109

134. Laforest A, Bretagnol F, Mouazan AS, Maggiori L, Ferron M, Panis Y (2012) Functional disorders after rectal cancer resection: does a rehabilitation programme improve anal continence and quality of life? Color Dis 14:1231-1237. https://doi.org/10.1111/ j.1463-1318.2012.02956.x

135. Allgayer H, Dietrich CF, Rohde W, Koch GF, Tuschhoff T (2005) Prospective comparison of short- and long-term effects of pelvic floor exercise/biofeedback training in patients with fecal incontinence after surgery plus irradiation versus surgery alone for colorectal cancer: clinical, functional and endoscopic/endoson. Scand
J Gastroenterol 40:1168-1175. https://doi.org/10.1080/ 00365520510023477

136. Liang Z, Ding W, Chen W, Wang Z, du P, Cui L (2016) Therapeutic evaluation of biofeedback therapy in the treatment of anterior resection syndrome after sphincter-saving surgery for rectal cancer. Clin Colorectal Cancer 15:e101-e107. https://doi. org/10.1016/j.clcc.2015.11.002

137. Blair GK, Djonlic K, Fraser GC, Arnold WD, Murphy JJ, Irwin B (1992) The bowel management tube: an effective means for controlling fecal incontinence. J Pediatr Surg 27:1269-1272. https:// doi.org/10.1016/0022-3468(92)90271-8

138. Del Popolo G, Mosiello G, Pilati C et al (2008) Treatment of neurogenic bowel dysfunction using transanal irrigation: a multicenter Italian study. Spinal Cord 46:517-522. https://doi.org/10. 1038/sj.sc.3102167

139. Christensen P, Krogh K (2010) Transanal irrigation for disordered defecation: a systematic review. Scand J Gastroenterol 45:517527. https://doi.org/10.3109/00365520903583855

140. Christensen P, Krogh K, Buntzen S, Payandeh F, Laurberg S (2009) Long-term outcome and safety of transanal irrigation for constipation and fecal incontinence. Dis Colon Rectum 52:286292. https://doi.org/10.1007/DCR.0b013e3181979341

141. Rosen H, Robert-Yap J, Tentschert G, Lechner M, Roche B (2011) Transanal irrigation improves quality of life in patients with low anterior resection syndrome. Color Dis 13:e335-e338. https://doi.org/10.1111/j.1463-1318.2011.02692.x

142. Martellucci J, Sturiale A, Bergamini C, Boni L, Cianchi F, Coratti A, Valeri A (2018) Role of transanal irrigation in the treatment of anterior resection syndrome. Tech Coloproctol 22:519-527. https://doi.org/10.1007/s10151-018-1829-7

143. Ratto C, Grillo E, Parello A, Petrolino M, Costamagna G, Doglietto GB (2005) Sacral neuromodulation in treatment of fecal incontinence following anterior resection and chemoradiation for rectal cancer. Dis Colon Rectum 48:1027-1036. https://doi.org/ 10.1007/s10350-004-0884-5

144. De Miguel M, Oteiza F, Ciga MA et al (2011) Sacral nerve stimulation for the treatment of faecal incontinence following low anterior resection for rectal cancer. Color Dis 13:72-77. https:// doi.org/10.1111/j.1463-1318.2009.02066.x

145. Jarrett MED, Matzel KE, Stösser M, Christiansen J, Rosen H, Kamm MA (2005) Sacral nerve stimulation for faecal incontinence following a rectosigmoid resection for colorectal cancer. Int J Color Dis 20:446-451. https://doi.org/10.1007/s00384-0040729-7

146. Holzer B, Rosen HR, Zaglmaier W, Klug R, Beer B, Novi G, Schiessel R (2008) Sacral nerve stimulation in patients after rectal resection-preliminary report. J Gastrointest Surg 12:921-925. https://doi.org/10.1007/s11605-008-0485-Z

147. Moya P, Arroyo A, Soriano-Irigaray L, Frangi A, Candela Polo F, Calpena Rico R (2012) Sacral nerve stimulation in patients with severe fecal incontinence after rectal resection. Tech Coloproctol $16: 263-264$

148. Schwandner O (2013) Sacral neuromodulation for fecal incontinence and "low anterior resection syndrome" following neoadjuvant therapy for rectal cancer. Int J Color Dis 28:665-669. https:// doi.org/10.1007/s00384-013-1687-8

149. Ramage L, Qiu S, Kontovounisios C, Tekkis P, Rasheed S, Tan E (2015) A systematic review of sacral nerve stimulation for low anterior resection syndrome. Color Dis 17:762-771. https://oi. org/10.1111/codi. 12968

150. Tan E, Ngo N-T, Darzi A, Shenouda M, Tekkis PP (2011) Metaanalysis: sacral nerve stimulation versus conservative therapy in the treatment of faecal incontinence. Int J Color Dis 26:275-294. https://doi.org/10.1007/s00384-010-1119-y

151. Matzel KE, Stadelmaier U, Bittorf B, Hohenfellner M, Hohenberger W (2002) Bilateral sacral spinal nerve stimulation 
for fecal incontinence after low anterior rectum resection. Int $\mathrm{J}$ Color Dis 17:430-434. https://doi.org/10.1007/s00384-0020412-9

152. De Meyere C, Nuytens F, Parmentier I, D'Hondt M (2020) Fiveyear single center experience of sacral neuromodulation for isolated fecal incontinence or fecal incontinence combined with low anterior resection syndrome. Tech Coloproctol. https://doi.org/ 10.1007/s10151-020-02245-2

153. Ram E, Meyer R, Carter D, Gutman M, Rosin D, Horesh N (2020) The efficacy of sacral neuromodulation in the treatment of low anterior resection syndrome: a systematic review and meta-analysis. Tech Coloproctol 24:803-815. https://doi.org/10.1007/ s10151-020-02231-8

154. Huang Y, Koh CE (2019) Sacral nerve stimulation for bowel dysfunction following low anterior resection: a systematic review and meta-analysis. Color Dis Off J Assoc Coloproctology Gt Britain Irel 21:1240-1248. https://doi.org/10.1111/codi.14690

155. D'Hondt M, Nuytens F, Kinget L, Decaestecker M, Borgers B, Parmentier I (2017) Sacral neurostimulation for low anterior resection syndrome after radical resection for rectal cancer: evaluation of treatment with the LARS score. Tech Coloproctol 21:301307. https://doi.org/10.1007/s10151-017-1612-1

156. Horrocks EJ, Thin N, Thaha MA, Taylor SJC, Norton C, Knowles CH (2014) Systematic review of tibial nerve stimulation to treat faecal incontinence. Br J Surg 101:457-468. https://doi.org/10.1002/bjs.9391

157. Knowles CH, Horrocks EJ, Bremner SA et al (2015) Percutaneous tibial nerve stimulation versus sham electrical stimulation for the treatment of faecal incontinence in adults (CONFIDeNT): a double-blind, multicentre, pragmatic, parallel-group, randomised controlled trial. Lancet (London, England) 386:1640-1648. https:// doi.org/10.1016/S0140-6736(15)60314-2

158. Lange MM, Marijnen CAM, Maas CP, Putter H, Rutten HJ, Stiggelbout AM, Kranenbarg EMK, van de Velde CJH (2009) Risk factors for sexual dysfunction after rectal cancer treatment. Eur J Cancer 45:1578-1588. https://doi.org/10.1016/j.ejca.2008.12.014

159. Doeksen A, Gooszen JAH, van Duijvendijk P, Tanis PJ, Bakx R, Slors JFM, van Lanschot JJB (2011) Sexual and urinary functioning after rectal surgery: a prospective comparative study with a median follow-up of 8.5 years. Int J Color Dis 26:1549-1557. https://doi.org/10.1007/s00384-011-1288-3

160. Bregendahl S, Emmertsen KJ, Lindegaard JC, Laurberg S (2015) Urinary and sexual dysfunction in women after resection with and without preoperative radiotherapy for rectal cancer: a populationbased cross-sectional study. Color Dis 17:26-37. https://doi.org/ 10.1111/codi. 12758

161. Schmidt C, Daun A, Malchow B, Kuchler T (2010) Sexual impairment and its effects on quality of life in patients with rectal cancer. Dtsch Arztebl Int 107:123-130. https://doi.org/10.3238/ arztebl.2010.0123

162. Maurer CA (2005) Urinary and sexual function after total mesorectal excision. Recent Results Cancer Res

163. Böhm G, Kirschner-Hermanns R, Decius A, Heussen N, Schumpelick V, Willis S (2008) Anorectal, bladder, and sexual function in females following colorectal surgery for carcinoma. Int J Color Dis 23:893-900. https://doi.org/10.1007/s00384-0080498-9

164. Vironen JH, Kairaluoma M, Aalto AM, Kellokumpu IH (2006) Impact of functional results on quality of life after rectal cancer surgery. Dis Colon Rectum 49:568-578. https://doi.org/10.1007/ s10350-006-0513-6

165. Lee DK, Jo MK, Song K, Park JW, Moon SM (2010) Voiding and sexual function after autonomic-nerve-preserving surgery for rectal cancer in disease-free male patients. Korean J Urol 51:858862. https://doi.org/10.4111/kju.2010.51.12.858

166. Celentano V, Fabbrocile G, Luglio G, Antonelli G, Tarquini R, Bucci L (2010) Prospective study of sexual dysfunction in men with rectal cancer: feasibility and results of nerve sparing surgery. Int J Color Dis 25:1441-1445. https://doi.org/10.1007/s00384010-0995-5

167. Lange MM, Maas CP, Marijnen CAM, Wiggers T, Rutten HJ, Kranenbarg EK, van de Velde CJH, cooperative clinical investigators of the Dutch Total Mesorectal Excision trial (2008) Urinary dysfunction after rectal cancer treatment is mainly caused by surgery. Br J Surg 95:1020-1028. https://doi.org/10.1002/bjs.6126

168. Kim NK (2005) Anatomic basis of sharp pelvic dissection for curative resection of rectal cancer. Yonsei Med J

169. Song PH, Yun SM, Kim JH, Moon KH (2010) Comparison of the erectile function in male patients with rectal cancer treated by preoperative radiotherapy followed by surgery and surgery alone. Int $\mathrm{J}$ Color Dis 25:619-624. https://doi.org/10.1007/s00384-010-0879-8

170. Marijnen CAM, van de Velde CJH, Putter H, van den Brink M, Maas CP, Martijn H, Rutten HJ, Wiggers T, Kranenbarg EK, Leer JWH, Stiggelbout AM (2005) Impact of short-term preoperative radiotherapy on health-related quality of life and sexual functioning in primary rectal cancer: report of a multicenter randomized trial. J Clin Oncol 23: 1847-1858. https://doi.org/10.1200/JCO.2005.05.256

171. Duchalais E, Larson DW, Machairas N, Mathis KL, Dozois EJ, Kelley SR (2019) Outcomes of early removal of urinary catheter following rectal resection for cancer. Ann Surg Oncol 26:79-85. https://doi.org/10.1245/s10434-018-6822-x

172. Okrainec A, Aarts M-A, Conn LG et al (2017) Compliance with urinary catheter removal guidelines leads to improved outcome in enhanced recovery after surgery patients. J Gastrointest Surg Off J Soc Surg Aliment Tract 21:1309-1317. https://doi.org/10.1007/ s11605-017-3434-x

173. Xu L, Tao Z-Y, Lu J-Y, Zhang GN, Qiu HZ, Wu B, Lin GL, Xu T, Xiao Y (2019) A single-center, prospective, randomized clinical trial to investigate the optimal removal time of the urinary catheter after laparoscopic anterior resection of the rectum: study protocol for a randomized controlled trial. Trials 20:133. https://doi.org/10. 1186/s13063-019-3210-1

174. Hendren SK, O'Connor BI, Liu M et al (2005) Prevalence of male and female sexual dysfunction is high following surgery for rectal cancer. Ann Surg 242:212-223. https://doi.org/10.1097/01.sla. 0000171299.43954.ce

175. Pietrangeli A, Pugliese P, Perrone M, Sperduti I, Cosimelli M, Jandolo B (2009) Sexual dysfunction following surgery for rectal cancer - a clinical and neurophysiological study. J Exp Clin Cancer Res 28:128. https://doi.org/10.1186/1756-9966-28-128

176. Kim JH, Noh TIL, Oh MM et al (2011) Voiding dysfunction after total mesorectal excision in rectal cancer. Int Neurourol J 15:166171. https://doi.org/10.5213/inj.2011.15.3.166

177. Lange MM, Van De Velde CJH (2011) Urinary and sexual dysfunction after rectal cancer treatment. Nat Rev Urol

178. Ho VP, Lee Y, Stein SL, Temple LKF (2011) Sexual function after treatment for rectal cancer: a review. Dis Colon Rectum 54: 113-125. https://doi.org/10.1007/DCR.0b013e3181fb7b82

179. Toritani K, Watanabe J, Suwa Y, Suzuki S, Nakagawa K, Suwa H, Ishibe A, Ota M, Kunisaki C, Endo I (2019) The risk factors for urinary dysfunction after autonomic nerve-preserving rectal cancer surgery: a multicenter retrospective study at Yokohama Clinical Oncology Group (YCOG1307). Int J Color Dis 34: 1697-1703. https://doi.org/10.1007/s00384-019-03374-3

180. Imaizumi K, Tsukada Y, Komai Y, Nomura S, Ikeda K, Nishizawa Y, Sasaki T, Taketomi A, Ito M (2019) Prediction of urinary retention after surgery for rectal cancer using voiding efficiency in the $24 \mathrm{~h}$ following Foley catheter removal. Int J Color Dis 34:1431-1443. https://doi.org/10.1007/s00384-019-03333-y

181. Barry MJ, Fowler FJ, O'Leary MP et al (1992) The American Urological Association symptom index for benign prostatic hyperplasia. The Measurement Committee of the American Urological Association. J Urol 
182. Jackson S, Donovan J, Brookes S, Eckford S, Swithinbank L, Abrams P (1996) The Bristol female lower urinary tract symptoms questionnaire: development and psychometric testing. Br J Urol 77:805-812. https://doi.org/10.1046/j.1464-410x.1996.00186.x

183. Rosen RC, Riley A, Wagner G, Osterloh IH, Kirkpatrick J, Mishra A (1997) The international index of erectile function (IIEF): a multidimensional scale for assessment of erectile dysfunction. Urology 49: 822-830. https://doi.org/10.1016/s0090-4295(97)00238-0

184. Rosen R, Brown C, Heiman J et al (2000) The Female Sexual Function Index (FSFI): a multidimensional self-report instrument for the assessment of female sexual function. J Sex Marital Ther 26:191-208. https://doi.org/10.1080/009262300278597

185. Thyø A, Emmertsen KJ, Laurberg S (2018) The rectal cancer female sexuality score: development and validation of a scoring system for female sexual function after rectal cancer surgery. Dis Colon Rectum 61:656-666. https://doi.org/10.1097/DCR. 0000000000001064

186. Kneist W, Junginger T (2007) Long-term urinary dysfunction after mesorectal excision: a prospective study with intraoperative electrophysiological confirmation of nerve preservation. Eur J Surg Oncol 33:1068-1074. https://doi.org/10.1016/j.ejso.2007.03.027

187. Mari GM, Crippa J, Cocozza E, Berselli M, Livraghi L, Carzaniga P, Valenti F, Roscio F, Ferrari G, Mazzola M, Magistro C, Origi M, Forgione A, Zuliani W, Scandroglio I, Pugliese R, Costanzi ATM, Maggioni D (2019) Low ligation of inferior mesenteric artery in laparoscopic anterior resection for rectal cancer reduces genitourinary dysfunction: results from a randomized controlled trial (HIGHLOW trial). Ann Surg 269:1018-1024. https://doi.org/ 10.1097/SLA.0000000000002947

188. Jayne DG, Brown JM, Thorpe H, Walker J, Quirke P, Guillou PJ (2005) Bladder and sexual function following resection for rectal cancer in a randomized clinical trial of laparoscopic versus open technique. Br J Surg 92:1124-1132. https://doi.org/10.1002/bjs.4989

189. Yang L, Yu Y-Y, Zhou Z-G, Li Y, Xu B, Song JM, Liu HY, Jiang X (2007) Quality of life outcomes following laparoscopic total mesorectal excision for low rectal cancers: a clinical control study. Eur J Surg Oncol 33:575-579. https://doi.org/10.1016/j.ejso.2006.11.026

190. Asoglu O, Matlim T, Karanlik H, Atar M, Muslumanoglu M, Kapran Y, Igci A, Ozmen V, Kecer M, Parlak M (2009) Impact of laparoscopic surgery on bladder and sexual function after total mesorectal excision for rectal cancer. Surg Endosc 23:296-303. https://doi.org/10.1007/s00464-008-9870-7

191. McGlone ER, Khan O, Flashman K et al (2012) Urogenital function following laparoscopic and open rectal cancer resection: a comparative study. Surg Endosc 26:2559-2565. https://doi.org/ 10.1007/s00464-012-2232-5

192. Hur H, Bae SU, Kim NK, Min BS, Baik SH, Lee KY, Kim YT, Choi YD (2013) Comparative study of voiding and male sexual function following open and laparoscopic total mesorectal excision in patients with rectal cancer. J Surg Oncol 108:572-578. https://doi.org/10.1002/jso.23435

193. Andersson J, Abis G, Gellerstedt M, Angenete E, Angerås U, Cuesta MA, Jess P, Rosenberg J, Bonjer HJ, Haglind E (2014) Patient-reported genitourinary dysfunction after laparoscopic and open rectal cancer surgery in a randomized trial (COLOR II). Br J Surg 101:1272-1279. https://doi.org/10.1002/bjs.9550

194. Park SY, Choi GS, Park JS, Kim HJ, Ryuk JP, Yun SH (2014) Urinary and erectile function in men after total mesorectal excision by laparoscopic or robot-assisted methods for the treatment of rectal cancer: a case-matched comparison. World J Surg 38: 1834-1842. https://doi.org/10.1007/s00268-013-2419-5

195. Yamaoka Y, Kagawa H, Shiomi A, Yamakawa Y, Hino H, Manabe S, Kinugasa Y (2020) Robotic-assisted surgery may be a useful approach to protect urinary function in the modern era of diverse surgical approaches for rectal cancer. Surg Endosc. https:// doi.org/10.1007/s00464-020-07509-4
196. Broholm M, Pommergaard H-C, Gögenür I (2015) Possible benefits of robot-assisted rectal cancer surgery regarding urological and sexual dysfunction: a systematic review and meta-analysis. Color Dis Off J Assoc Coloproctology Gt Britain Irel 17:375381. https://doi.org/10.1111/codi.12872

197. Tang X, Wang Z, Wu X, Yang M, Wang D (2018) Robotic versus laparoscopic surgery for rectal cancer in male urogenital function preservation, a meta-analysis. World J Surg Oncol 16:196. https:// doi.org/10.1186/s12957-018-1499-y

198. Kim MJ, Park SC, Park JW, Chang HJ, Kim DY, Nam BH, Sohn DK, Oh JH (2018) Robot-assisted versus laparoscopic surgery for rectal cancer: a phase II open label prospective randomized controlled trial. Ann Surg 267:243-251. https://doi.org/10.1097/SLA. 0000000000002321

199. Celentano V, Cohen R, Warusavitarne J, Faiz O, Chand M (2017) Sexual dysfunction following rectal cancer surgery. Int J Color Dis 32:1523-1530. https://doi.org/10.1007/s00384-017-2826-4

200. Canada AL, Neese LE, Sui D, Schover LR (2005) Pilot intervention to enhance sexual rehabilitation for couples after treatment for localized prostate carcinoma. Cancer 104:2689-2700. https://doi. org/10.1002/cncr.21537

201. Nishizawa Y, Ito M, Saito N, Suzuki T, Sugito M, Tanaka T (2011) Male sexual dysfunction after rectal cancer surgery. Int J Color Dis 26: 1541-1548. https://doi.org/10.1007/s00384-011-1247-z

202. Park SY, Choi G-S, Park JS, Kim HJ, Park JA, Choi JI (2015) Efficacy and safety of udenafil for the treatment of erectile dysfunction after total mesorectal excision of rectal cancer: a randomized, double-blind, placebo-controlled trial. Surgery 157:64-71. https://doi.org/10.1016/j.surg.2014.07.007

203. Apostolidis A, Dasgupta P, Denys P, Elneil S, Fowler CJ, Giannantoni A, Karsenty G, Schulte-Baukloh H, Schurch B, Wyndaele JJ, European Consensus Panel (2009) Recommendations on the use of botulinum toxin in the treatment of lower urinary tract disorders and pelvic floor dysfunctions: a European consensus report. Eur Urol 55:100-120

204. Dulskas A, Smolskas E, Kildusiene I, Samalavicius NE (2018) Treatment possibilities for low anterior resection syndrome: a review of the literature. Int J Color Dis 33:251-260. https://doi.org/ 10.1007/s00384-017-2954-x

205. Drake MJ (2008) Mechanisms of action of intravesical botulinum treatment in refractory detrusor overactivity. BJU Int 102:11-16

206. Herbison GP, Arnold EP (2009) Sacral neuromodulation with implanted devices for urinary storage and voiding dysfunction in adults. Cochrane Database Syst Rev

207. Thomas G, van Heinsbergen M, van der Heijden J, Slooter G, Konsten J, Maaskant S (2019) Awareness and management of low anterior resection syndrome: a Dutch national survey among colorectal surgeons and specialized nurses. Eur J Surg Oncol J Eur Soc Surg Oncol Br Assoc Surg Oncol 45:174-179. https://doi.org/ 10.1016/j.ejso.2018.11.001

208. Garfinkle R, Wong-Chong N, Petrucci A, Sylla P, Wexner SD, Bhatnagar S, Morin N, Boutros M (2019) Assessing the readability, quality and accuracy of online health information for patients with low anterior resection syndrome following surgery for rectal cancer. Color Dis Off J Assoc Coloproctology Gt Britain Irel 21: 523-531. https://doi.org/10.1111/codi.14548

209. van der Heijden JAG, Thomas G, Caers F, van Dijk WA, Slooter GD, Maaskant-Braat AJG (2018) What you should know about the low anterior resection syndrome - clinical recommendations from a patient perspective. Eur J Surg Oncol J Eur Soc Surg Oncol Br Assoc Surg Oncol 44:1331-1337. https://doi.org/10.1016/j.ejso.2018.05.010

Publisher's note Springer Nature remains neutral with regard to jurisdictional claims in published maps and institutional affiliations. 